\title{
The topographic evolution of the Tibetan Region as revealed by palaeontology
}

\author{
Robert A. Spicer ${ }^{1,2,3}$ (D) Tao Su ${ }^{1,2} \cdot$ Paul J. Valdes ${ }^{4} \cdot$ Alexander Farnsworth $^{4} \cdot$ Fei-Xiang $\mathrm{Wu}^{5} \cdot$ Gongle Shi $^{6}$. \\ Teresa E. V. Spicer ${ }^{1} \cdot$ Zhekun Zhou $^{1,2}$
}

Received: 22 February 2020 / Revised: 14 May 2020 / Accepted: 2 September 2020 / Published online: 27 November 2020

(C) The Author(s) 2020

\begin{abstract}
The Tibetan Plateau was built through a succession of Gondwanan terranes colliding with Asia during the Mesozoic. These accretions produced a complex Paleogene topography of several predominantly east-west trending mountain ranges separated by deep valleys. Despite this piecemeal assembly and resultant complex relief, Tibet has traditionally been thought of as a coherent entity rising as one unit. This has led to the widely used phrase 'the uplift of the Tibetan Plateau', which is a false concept borne of simplistic modelling and confounds understanding the complex interactions between topography climate and biodiversity. Here, using the rich palaeontological record of the Tibetan region, we review what is known about the past topography of the Tibetan region using a combination of quantitative isotope and fossil palaeoaltimetric proxies, and present a new synthesis of the orography of Tibet throughout the Paleogene. We show why 'the uplift of the Tibetan Plateau' never occurred, and quantify a new pattern of topographic and landscape evolution that contributed to the development of today's extraordinary Asian biodiversity.
\end{abstract}

Keywords Tibet $\cdot$ Himalaya $\cdot$ Hengduan Mountains $\cdot$ Palaeoaltimetry $\cdot$ Fossils $\cdot$ Climate

\section{Introduction}

The modern Tibetan Plateau (Fig. 1) is the highest and most extensive elevated surface on Earth covering an area of $2,500,000 \mathrm{~km}^{2}$ at an average elevation above $4500 \mathrm{~m}$. The boundaries of the plateau extend $1000 \mathrm{~km}$ northwards from the Yarlung-Tsangpo suture zone (YTSZ), south of which is the Himalayan thrust belt, to the Altyn Tagh fault. Westwards the plateau boundary is marked by the Karakoram strike-slip fault, while $2000 \mathrm{~km}$ to the east the plateau morphs into the Hengduan Mountains and down into Yunnan and Sichuan.

In conjunction with the adjacent Himalaya and Hengduan Mountain systems (Fig. 1), the Tibetan Plateau is often referred to as 'The Third Pole' (Qiu 2008) and regarded as the 'Water Tower' (Viviroli et al. 2007; Immerzeel et al. 2020) of Asia. This is because its hydrological services, delivered through the Yangtse, Yellow, Red, Mekong, Salween, Tsangpo-Brahmaputra, Indus and Ganges rivers that all

This article is a contribution to the special issue Palaeobotanical contributions in honour of Volker Mosbrugger

Robert A. Spicer

r.a.spicer@open.ac.uk

1 CAS Key Laboratory of Tropical Forest Ecology, Xishuangbanna Tropical Botanical Garden, Chinese Academy of Sciences, Mengla 666303, China

2 Center of Plant Ecology, Core Botanical Gardens, Chinese Academy of Sciences, Mengla 666303, China

3 School of Environment, Earth and Ecosystem Sciences, The Open University, Milton Keynes MK7 6AA, UK
4 School of Geographical Sciences, University of Bristol, Bristol BS8 1SS, UK

5 Key Laboratory of Vertebrate Evolution and Human Origins, Institute of Vertebrate Paleontology and Paleoanthropology, Chinese Academy of Sciences, Beijing 100044, China

State Key Laboratory of Palaeobiology and Stratigraphy, Nanjing Institute of Geology and Palaeontology and Center for Excellence in Life and Paleoenvironment, Chinese Academy of Sciences, Nanjing 210008, China 
(a)

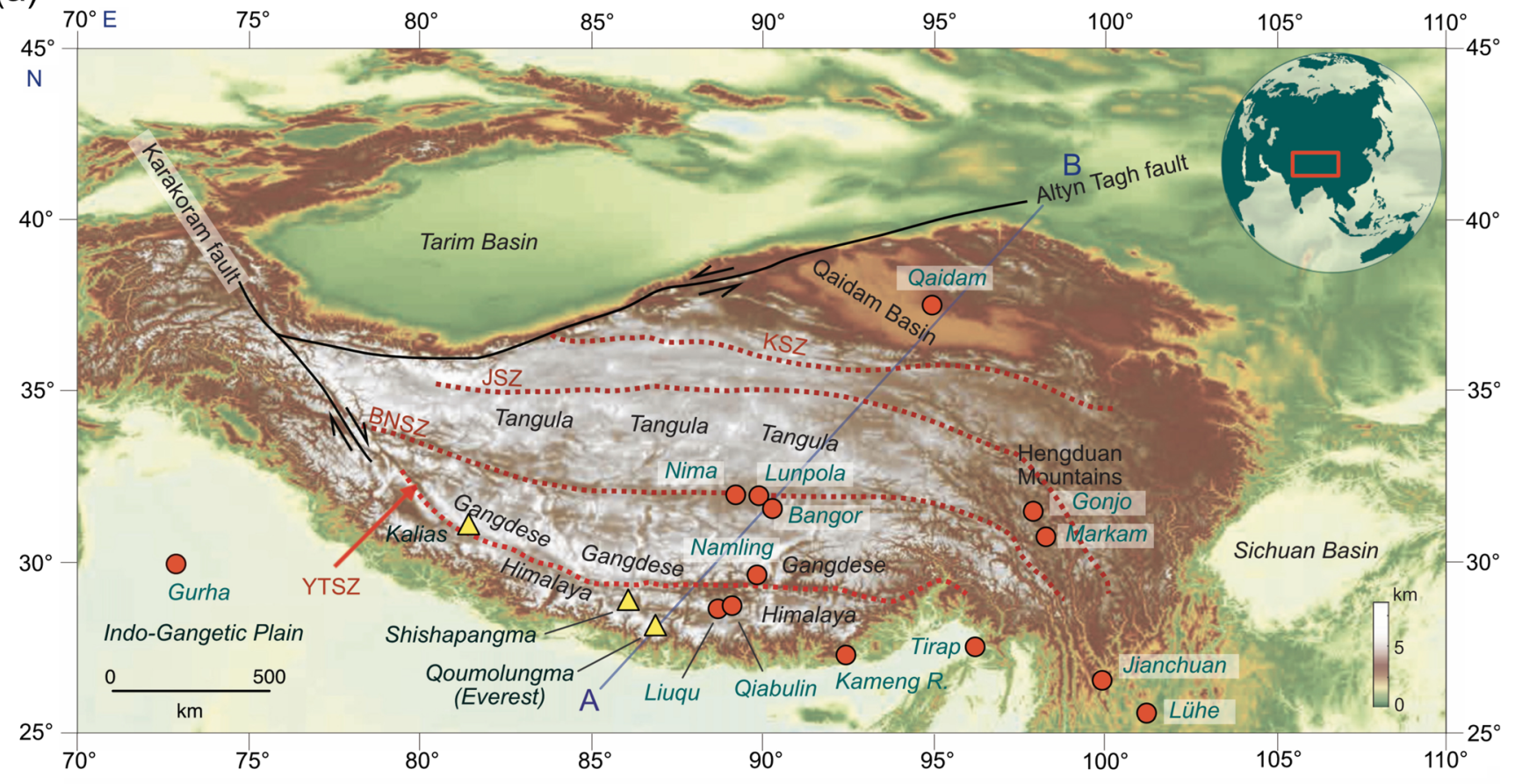

(b) $\mathrm{A}$

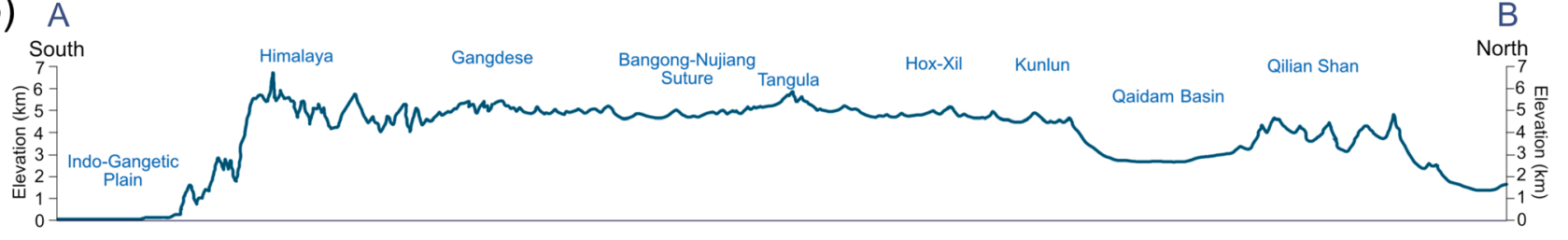

Fig. 1 a Global locator (inset) and orographic map of the Tibetan region showing major bounding features, sutures and major fossiliferous basins (red circles) referred to in the text. Yellow triangles mark the positions of mountain peaks featured in the text. YTSZ-Yarlung-Tsangpo Suture

originate on or near the plateau, dominate the lives and livelihoods of people throughout most of Asia. By understanding the evolution of The Third Pole, we also obtain a better understanding of significant components of the modern Earth system and how they may change in the future.

For many years, the height and extent of the Tibetan Plateau and surrounding mountains have been regarded as the main drivers of the Asian monsoon, with summer heating of the atmosphere over the plateau creating a deep low-pressure system that draws in moist air from the Indian Ocean, while winter cooling creates a strong high-pressure system reversing the air flow and flooding the surrounding regions with dry air (Flohn 1968; Yanai and $\mathrm{Wu} 2006$ ). The plateau has therefore been envisioned to act as a sensible heat pump. However, because the location of the greatest heating is not over the plateau, but over NW India and eastern Pakistan, the Himalaya are also regarded as having a key orographic influence on the monsoon (Boos and Kuang 2010; Molnar et al. 2010), although recent modelling shows that monsoon circulation would exist even in the absence of an orographic barrier (Acosta and Huber 2020).
Zone; BNSZ_-Bangong-Nujiang Suture Zone; JSZ_Jinsha Suture Zone; KSZ - Kunlun Suture Zone. b Modern topographic profile along the transect A-B shown in (a)

The topographically complex domain of the Tibetan region contributes to, and experiences, a monsoon climate over much of its extent. The Asian monsoon systems also impact several of the world's great centres of biotic richness, namely the Indo-Burma, the South-Central China and Western Ghats biodiversity 'hotspots' (Myers et al. 2000). In addition to the region's climatic and biotic significance, Tibet, and the geology of the associated mountain systems, provides unique insights into collision tectonics and geodynamic processes. Despite this importance, and even after decades of research, the orographic evolution of the region remains imperfectly known.

Our conceptual framework for the evolution of the Tibetan region has been compromised by commonly held myths embedded in the literature of the geosciences and the wider research community (Spicer et al. 2020a, b). One such myth is exemplified in the commonly used phrase 'the uplift of the Tibetan Plateau', which implies that a flat-surfaced (low relief) Tibet rose as a coherent entity. Moreover, it is not unusual to find that the Tibetan Plateau and the Himalaya are 
aggregated into a single entity, which is unfortunate because this conflation obscures the distinctly different processes underlying their formation. Similarly, the monsoon climates experienced throughout the region represent not one system, but an aggregation of interacting monsoon types, each with its own pattern of evolution and causal drivers, and each with different heterogeneous impacts on biodiversity in time and space (Spicer et al. 2017; Wang et al. 2017a).

In this work, the Himalaya-Tibet-Hengduan Mountains area will be referred to as the 'Tibetan region' because using any term relating to the modern topography, and particularly references to a 'plateau', prejudices our view of the past. Similarly, the terms 'Tibetan Plateau' or 'Qinghai Tibetan Plateau' are retained just for the present day. To refer to a 'plateau' in the Paleogene is incorrect and conceptually misleading. The area occupied by the present plateau will simply be referred to as 'Tibet' without any real or implied topographic or administrative connotations.

Linked to this simple monolithic concept of Tibet is the idea that the uplift took place very recently in the late Neogene (Miocene-Pliocene) (Xu et al. 1973; Wang et al. 2006; Harrison et al. 1992; Molnar et al. 1993; Coleman and Hodges 1995; Zhou et al. 2007; Chang et al. 2010; Sun et al. 2014a, 2015b). Part of the problem here lies in models that treat Tibet and the adjacent mountain systems as a single block, leading to the assumption that surface height determined at a particular location indicates uplift of the whole Tibetan region. This clearly need not be the case, and while individual measurements may (or may not) be valid they only apply to the specific locations where they were made.

Another misconception is that the mechanism for this monolithic rise was purely the collision of India with Eurasia beginning early in the Paleogene (see review by Wang et al. 2014). There can be no doubt that the collision had far-reaching consequences, and is even invoked to explain re-activation of the Central Asian Orogenic Belt from Lake Baikal into Siberia (Molnar and Tapponier 1975; Dobretsov et al. 1996), but not all Tibet's topography was formed by the India-Eurasia collision. Significant uplands, created by earlier terrane accretions, existed across the Tibetan region before the arrival of India.

In the last few years, improvements in our understanding of regional geology, fossil biotas and, crucially, radiometric dating has transformed our ideas of how 'The Third Pole' topography evolved, and that a wide variety of tectonic modes have operated over the past $\sim 220 \mathrm{Ma}$ to produce it (e.g. Dewey et al. 1988; Liu et al. 2016; Kapp and DeCelles 2019). We attempt to bring together these different strands of evidence, focusing on topographic evolution because it is topography, and not the underlying geology, that has most impact on atmospheric dynamics and the biota. We highlight recent palaeontological finds that have been crucial to bringing about a transformation in the way we envisage the Tibetan region developing, and explore why palaeoaltimetry based on the biota differs so much from that derived from stable isotopes. Finally, we synthesise the Paleogene topographic development of the Tibetan region and discuss its relationship to monsoon characteristics and the evolution of Asian biodiversity.

\section{The assembly of Tibet}

There is long-standing evidence that Tibet evolved in a piecemeal manner (England and Searle 1986; Dewey et al. 1988; Fielding 1996; Tapponnier et al. 2001), and that Tibet is not a single monolithic block but an amalgam of Gondwanan terranes accreted successively onto the Eurasia plate. This assembly spanned more than 200 million years beginning in the early Mesozoic (Allègre et al. 1984; Burg and Chen 1984; Șengör 1984; Dewey et al. 1988; Yin and Harrison 2000; Metcalfe 2006; Guillot et al. 2019), India being the most recent terrane to accrete to Eurasia early in the Cenozoic. From north to south, the modern Tibetan Plateau comprises the Kunlun-Qaidam, Hoh Xil-Songpan Ganzi, Qiangtang and Lhasa terranes (Fig. 2). At the junctions of these tectonic blocks, again going from north to south, are major suture zones: the Ayimaqin-Kunlun Suture Zone (AKSZ) between the Kunlun-Qaidam and the Hoh Xil-Songpan Ganzi terranes, the Jingsha Suture Zone (JSZ) between the Hoh XilSongpan Ganzi and the Qaidam terranes, and the BangongNujiang Suture Zone (BNSZ) between the Qaidam and Lhasa blocks. The Yarlung-Tsangpo Suture Zone (YTSZ) marks the junction between the Lhasa block and the Indian Plate (Fig. 2).

The assembly of Tibet began in the Late Triassic to Early Jurassic with the arrival of the Kunlun-Qaidam and Qiangtang terranes (Roger et al. 2003; Gehrels et al. 2011), followed by the Qiangtang and Lhasa block collision in the Early Cretaceous (Kapp et al. 2005). The early Paleogene (55 $\pm 10 \mathrm{Ma}$ ) seems to be the preferred date for the onset of the India-Lhasa terrane collision for many authors (Beck et al. 1995; Rowley 1996; Acton 1999; Sigoyer et al. 2000; Aitchison et al. 2002; Leech et al. 2005; Zhu et al. 2005; Garzanti 2008; Guillot et al. 2008; Copley et al. 2010; Liebke et al. 2010; St-Onge et al. 2010; Cai et al. 2011; Wang et al. 2011; Hu et al. 2012; Meng et al. 2012; White et al. 2012; Zahirovic et al. 2012; Zhang et al. 2012b; Bouilhol et al. 2013; Li et al. 2013; Wang et al. 2014), but there are significant outliers in these estimates that span $65 \mathrm{Ma}$ (Yin and Harrison 2000; Ding et al. 2005) to $20 \mathrm{Ma}$ (van Hinsbergen et al. 2012).

The lack of consensus over the timing of the onset of the collision is in part due to confusion over what is meant by the 'onset of collision'. For biologists, the important moment is when a land connection is first established allowing free exchange of terrestrial biota, while for a geologist it may be when oceanic lithosphere finally disappears even though a 


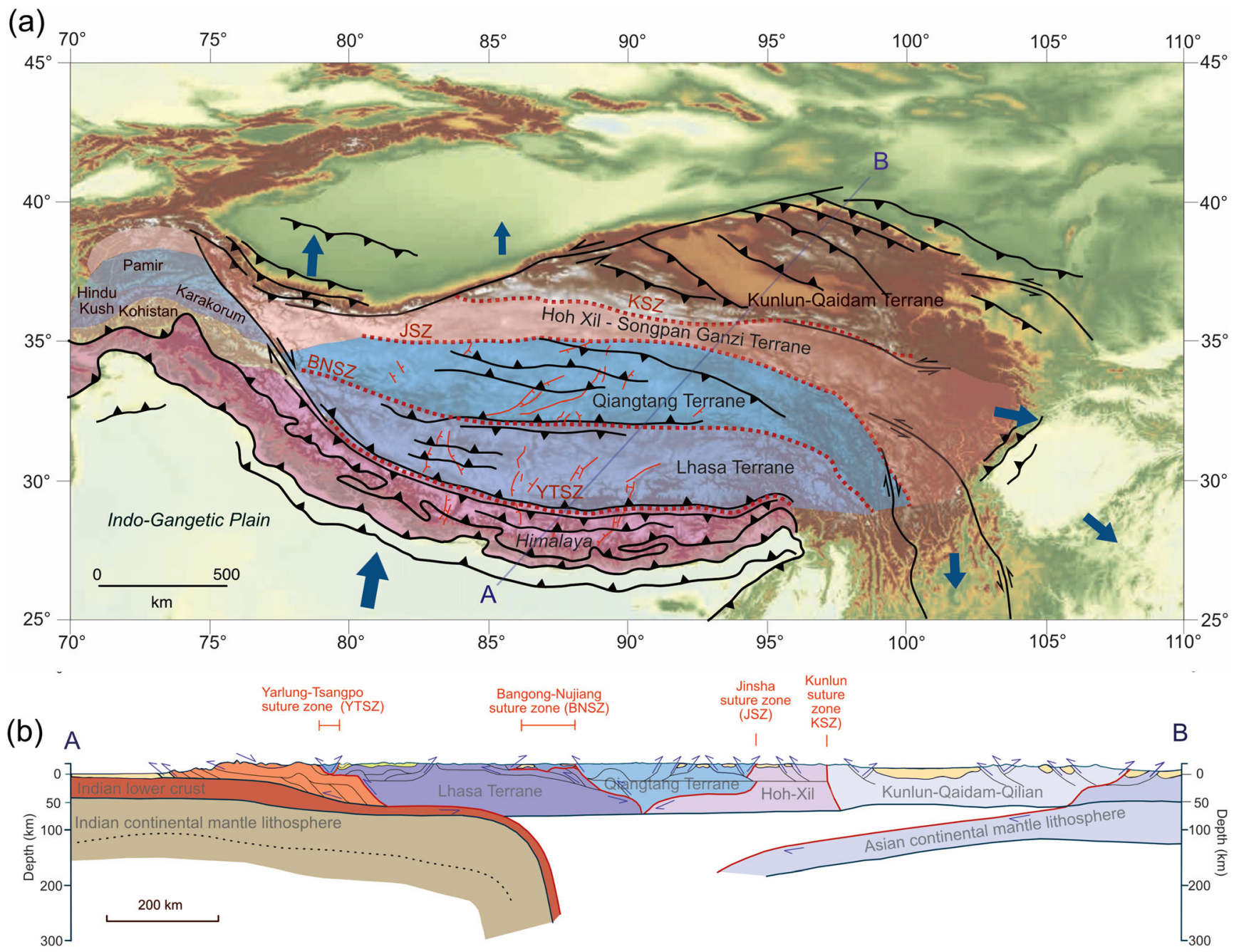

Fig. 2 a Map of the Tibetan region showing the major terranes, suture zones (dotted red lines), thrusts (black lines) and normal (extensional) faults (red lines); blue arrows of different sizes indicated the modern primary directions and relative rates of present-day surface motion derived from GPS measurements (Gan et al. 2007); KSZ - Kunlun Suture

marine 'moat' may persist long after. Another source of confusion arises from disparities in palaeomagnetic data. To attempt to reconcile these differences, the concept of a Greater Indian Basin (GIB) has been proposed (van Hinsbergen et al. 2012, 2019; Huang et al. 2015). This envisages rifting and seafloor spreading from $\sim 120$ to $\sim 70$ Ma within an oceanic basin, the GIB, between what is now the Tethyan Himalaya and stable India (van Hinsbergen et al. 2012). This affects the amount of subducted material and also the timing of the onset of continental collision. In a recent re-examination of palaeomagnetic data, Rowley (2019a) found no support for the GIB concept, although Rowley's analysis has been challenged (van Hinsbergen 2019) and that challenge rebutted (Rowley 2019b).

The timing of the establishment of a land bridge enabling easy biotic exchange between India and Eurasia has long been argued over (Chatterjee and Scotese 1999; Prasad and Sahni

Zone; JSZ_-Jingsha Suture Zone; BNSZ_-Bangong-Nujiang Suture Zone; YTSZ-Yarlung-Tsangpo Suture Zone; compiled from Wang et al. (2014) and Guillot et al. (2019). b Inferred vertical profile along the transect A-B shown in (a); simplified from Kapp and DeCelles (2019)

1999; Whatley and Bajpai 2000; Briggs 2003; Sahni and Prasad 2008; Datta-Roy and Karanth 2009; Samant et al. 2013; Klaus et al. 2016), particularly as Cretaceous sediments in India host fossils with non-Gondwanan affinities (Jaeger et al. 1989; Sahni and Bajpai 1991; Prasad and Sahni 1999; Samant et al. 2013). A recent molecular phylogenetic study using dated fossils to constrain an analysis of 50 mammalian lineages argues for free exchange between India and Eurasia as early as 64.8-61.3 Ma in the Danian (Ni et al. 2020). This is at the oldest extreme of the likely collisional age $(55 \pm 10 \mathrm{Ma})$ that emerged from the literature review of Wang et al. (2014), but it does not mean a land connection existed along the whole length of the southern margin of Tibet because the most recent marine sediments in the central part of southern Tibet only disappear at $\sim 50 \mathrm{Ma}$ (Ding et al. 2005; Najman et al. 2010).

Each of the accretion events that built Tibet would have thickened the crust, subducted ocean and continental 
lithosphere, and resulted in surface relief. This means that when India arrived, Tibet already exhibited an inherited complex topography and underlying geology, so subsequent compression from the northward passage of India will have idiosyncratically produced different responses in different parts of the Tibetan region at different times (Kelley et al. 2019), and not automatically produced a plateau. During accretion and compression, a combination of fault/suture re-activation, local subduction, slab break-off, lower lithospheric ductile flow and even localised thermal thinning of the lower lithosphere (England and Houseman 1988) would have produced a complex surface relief interacting with atmospheric dynamics and biodiversity. It is essential to quantify the evolution of topography throughout the Tibetan region if we are to disentangle properly the complex interactions between surface height, climate systems (particularly monsoons) and biodiversity (Spicer 2017).

\section{Palaeoaltimetry}

Measuring past surface height is not straightforward, and always has to be inferred via various assumptions as to how a geological observation or measurement can be transformed into a quantitative estimate of elevation. Before reviewing these assumptions, we need clarity regarding terminology because the poor use of terms has contributed significantly to misconceptions regarding orogeny, and its consequences, in the Tibetan region.

\section{Uplift and exhumation}

The term 'uplift' has a particular meaning in geology and relates to a process in which work is done against gravity, and is defined as a vector opposite to that of gravity. Any height change of a rock body 'must specify both a reference frame and the object that moves' (Molnar and England 1990, p. 30). That reference frame is usually the geoid (sea level corrected for eustatic changes) or some other point on Earth's surface whose height is known (relative to a reference frame). In a geological context, the object that moves relative to the reference frame need not be Earth's surface, but can be a sub-surface rock body. When a rock body rises against gravity (for example, the ascent through the crust of a granite pluton) and it approaches the surface, it cools, so sometimes cooling rates are interpreted in terms of uplift. However, this is potentially very misleading because erosion can lead to a reduction in surface height relative to that rock body and thus an increase in cooling rates. In this case, no work has been done against gravity.

The process of exhumation (rock removal from the Earth's surface) should never be confused with uplift; the two processes are quite different and have totally opposite implications for tectonics, climate, and biodiversity. Note, however, that erosion (removal of rock) often leads to isostatic rebound and thus uplift, which can result in further erosion. Such uplift is usually quite modest, and erosion is a function of climate as well as surface uplift. In the remainder of the present paper, we always refer to rocks at Earth's surface because it is the surface that provides the substrate for biodiversity and interacts with the atmosphere.

Erosion means removal of rock material, which is then usually transported away from the erosional site to be deposited elsewhere. This deposition can infill an enclosed basin and in so doing raise the height of the sediment surface occupying the basin lowlands. Even though the height of that surface has risen above the depositional basement, the underlying rocks forming that basement may not have moved with respect to the geoid and, if anything, are likely to have subsided due to sediment loading. In this case, no work has been done against gravity, and so the process of raising the surface height cannot be termed 'uplift'.

\section{Lapse rates}

Palaeoaltimetry is the measurement of past surface height, and changes thereof, against a reference frame or datum. Ideally, this datum should be the geoid, but eustatic sea level changes are often difficult to quantify, and therefore correct for, and are usually small compared with the uncertainties in palaeoaltimetric techniques. For an example of the potential complexity of sea level and other corrections in palaeoaltimetry, see Meyer (1992).

To measure past surface height, we need to measure changes in a physical parameter with elevation above a datum (e.g. sea level), and those changes need to be captured and preserved unchanged in the rock record. A common physical parameter that changes with increasing height above sea level (a lapse rate) is atmospheric temperature, and this gives rise to what are called 'thermal lapse rates'. Past surface temperatures can be archived in the form of geochemical proxies such as clumped isotopes (e.g. Huntingdon et al. 2015), biomarkers (Inglis et al. 2019; Naafs et al. 2019), the intrinsic thermal tolerances of specific plants or animals (e.g. Deng et al. 2019; Su et al. 2019), populations of plants and animals (Kershaw and Nix 1988; Mosbrugger and Utescher 1997; Utescher et al. 2014), or temperatures encoded in plant form (e.g. using leaf physiognomy-Wolfe 1979, 1993; Spicer et al. 2009; Yang et al. 2015). Thermal lapse rates can be based on mean annual temperatures, seasonal means or even monthly mean temperatures. Cold month mean lapse rates are particularly useful because many plants such as palms are sensitive to freezing (Reichgelt et al. 2018), whereas mean annual temperatures can disguise large variations in seasonal temperature, both extremes of which may be crucial to both biological (as captured in fossil remains, including 
biomarkers) and geological processes (e.g. mineralisation and clumped isotopes (Eiler 2007, 2011)).

For meteorological purposes, a thermal lapse rate is measured in a column of free air and such 'free air thermal lapse rates' are important for many atmospheric processes. Their ready availability means that free air lapse rates also have a long history of use in palaeoaltimetry (reviewed in Meyer 1992). However, free air lapse rates are not relevant to determining land surface heights because absorption and reradiation of heat, convective processes and air mass deflection at a surface lead to local lapse rates that are markedly different from those in a column of free air (Meyer 1992, 2007). In intermontane basins, where sediments accumulate, such lapse rates can even be negative (Wolfe 1992). These surface lapse rates, or 'terrestrial thermal lapse rates', are therefore the only ones that should be used for determining surface heights (Spicer 2018), but they have a crucial drawback in that they are location (e.g. distance from a shoreline) and, more importantly, topography dependant. This means the only realistic way of applying terrestrial thermal lapse rates is through empirical climate model mediation (e.g. Su et al. 2019).

Lapse rates are also used in stable isotope palaeoaltimetry. Here, the physical parameter that changes with height is the rate at which isotopic composition of atmospheric moisture changes with elevation when an air parcel is forced upwards on the windward side of a mountain range. Initially, this was investigated empirically (Garzione et al. 2000), but it was soon realised that a reasonably predictable process of Rayleigh fractionation takes place on the windward side of a mountain range, and that this provides a useful generic model for measuring palaeoelevation (Poage and Chamberlain 2001; Rowley et al. 2001; Rowley and Garzione 2007). As before, the elevation measurement is made with respect to a datum, and in stable isotope palaeoaltimetry that datum is the isotopic composition of water at a known height (usually sea level) at the start of the air parcel trajectory.

Rayleigh fractionation describes the effect of heavier isotopes being more likely to rain out from a parcel of air as it rises and cools than lighter isotopes, with the result that at progressively higher elevations the composition of rainwater gets more and more enriched with the lighter isotopes. A common isotope system used is that of oxygen $\left({ }^{18} \mathrm{O} /{ }^{16} \mathrm{O}\right)$, but the deuterium/hydrogen system can also be employed. Evaporation and plant transpiration (evapo-transpiration) also result in fractionation, and here the lighter isotopes tend to evaporate to the atmosphere more than the heavier ones, leaving the source water (or plant) enriched with the heavier isotope, and ideally such vegetation effects should be factored into palaeoelevation estimates (Mulch 2016). The reverse happens when water condenses: the heavier isotopes tend to rain out preferentially. It is worth noting that climate modelling has shown the Rayleigh fractionation model is temperature dependant (Poulsen and Jeffery 2011), such that in warmer climates the rate at which ${ }^{18} \mathrm{O}$ rains out of an air parcel is less than it would be in a cooler climate. In effect, this means that the isotopic lapse rate is reduced in warm climates.

In practice, there may be multiple cycles of evapotranspiration and precipitation along an air parcel trajectory (Blisnuik and Stern 2005). This produces the so-called continental effect (Winnick et al. 2014) that is important for inland sites (such as over central Tibet), but is difficult to quantify accurately unless the analysis is done in conjunction with an isotope-enabled climate model (Sturm et al. 2010) and the air parcel traced back to its source. Moreover, the isotopic composition of rainwater is not preserved in its raw state, but as minerals or organic materials formed in lakes, plants or soils (e.g. Quade et al. 2007) into, and upon which, the rain fell. Mineralisation and the formation of organics (often wood cellulose or leaf waxes) (e.g. Kim and O'Neil 1997; Polissar et al. 2009; Luo et al. 2011) introduces further fractionation, as does isotopic exchange with the surrounding host rocks during burial (diagenesis) and with any later meteoric waters that might penetrate the host system (Garzione et al. 2004; Leier et al. 2009). Nevertheless, with careful petrological examination, diagenetic effects can be detected, and compensated for, and highly altered samples rejected (Garzione et al. 2004).

\section{Moist enthalpy—a thermodynamic palaeoaltimeter}

Because thermal lapse rates are spatially and temporally variable and, crucially, dependant on the topography that is being investigated, their application in palaeoaltimetry is problematic. Coupled with several palaeothermometers being prone to diagenetic alteration (e.g. biomarkers, Naafs et al. 2019, and isotopes Rowley and Garzione 2007), there has long been a desire for a proxy that is more robust to these limitations. The proxy that has gained most widespread use in this respect exploits the encoding of an atmospheric property known as moist enthalpy in the architecture (physiognomy) of woody dicot leaf fossils (Forest et al. 1995, 1999; Spicer et al. 2003; Khan et al. 2014; Su et al. 2018).

Moist enthalpy $(H)$ is given as

$H=\left(c^{\prime} p T+L v q\right)$

where $c^{\prime} p$ is the specific heat capacity of moist air at a constant pressure, $T$ is temperature (in $\mathrm{K}$ ), $L v$ is the latent heat of vaporisation of water and $q$ is specific humidity.

Moist enthalpy $(H)$ and potential energy $(g Z)$ together make up the total energy contained in a parcel of air (kinetic energy is minimal in most circumstances and can be ignored) and this is known as moist static energy $(h)$

$h=H+g Z$

where $g$ is the acceleration due to gravity (a constant) and $Z$ is height. 
Because $h$ is mostly conserved as a parcel of air rises up the windward side of a mountain range, any difference in enthalpy between two locations, one low and one high $\left(H_{\text {low }}-H_{\text {high }}\right)$, divided by the acceleration due to gravity (the constant $g$ ) gives the height difference $(\Delta Z)$.

$\Delta Z=\left(H_{\text {low }}-H_{\text {high }}\right) / g$

Leaf fossils encode well the moist enthalpy they were exposed to when alive (Forest et al. 1999), but leaves are intrinsically vulnerable to being damaged if they are transported far from their growth site (Spicer 1981; Ferguson 1985; Spicer and Wolfe 1987). However, once buried and preserved, their features are not subject to the subtle diagenetic modification that can compromise isotope palaeoaltimetry. Character loss can occur through taphonomic processes and collecting, but provided a large enough assemblage of leaves representing different species are utilised, these losses only minimally affect analytical precision (Povey et al. 1994; Spicer et al. 2005). Moreover, even catastrophic loss of some characters, such as leaf size, does not degrade the ability to determine past surface height in any significant way because moist enthalpy is encoded in multiple leaf characters (Spicer and Yang 2010). Leaf susceptibility to pre-burial transport damage is actually advantageous in that it means that a diverse leaf assemblage inevitably represents vegetation growing close to, and crucially at the same elevation as, the depositional site.

Each proxy has its own inherent strengths and weaknesses so, ideally, they should be used in combination; each proxy tends to reflect different aspects of the palaeotopography of a region and so complement one another (Su et al. 2019). This complementarity is no better expressed than in the palaeoaltimetry of the Tibetan region.

\section{Paleogene topography of Tibet}

Prior accretions of the Songpan-Ganzi/Hox-Xil, Qiangtang and Lhasa terranes bequeathed a complex topography across Tibet at the start of the Paleogene, and parts of that relief in north-western Tibet have been preserved for at least $40 \mathrm{Ma}$ (Law and Allen 2019). In the early Paleogene, the southern margin of the Lhasa terrane may have been at a latitude of $10^{\circ} \mathrm{N}$ (Cao et al. 2017; Li et al. 2017b; Tong et al. 2017), but other estimates put it at $16.5 \pm 4^{\circ} \mathrm{N}$ in the Early Cretaceous (Huang et al. 2015), and with the northward movement of India it is unlikely that the Lhasa terrane subsequently drifted southwards. By the early Eocene, it is estimated to have been at $21-24^{\circ} \mathrm{N}$, moving another $8-10^{\circ} \mathrm{N}$ northward by the latest Oligocene (Meng et al. 2017).

\section{The rise of the Gangdese Mountains}

At the time of closure between the Lhasa and Qiangtang terranes in the late Early Cretaceous (Kapp and DeCelles 2019), a mountain chain or 'Cordilleran-style orogen' (Burg et al. 1983; Chang et al. 1986; England and Searle 1986; Coward et al. 1988; Ratschbacher et al. 1992; Kapp et al. 2007a, b; Kapp and DeCelles 2019) was already forming on the southern margin of the Lhasa terrane. To the north of these mountains, known as the Gangdese Arc, a shallow marine retro-arc foreland basin existed across the northern part of the Lhasa terrane, and this accumulated the sediments of the Takena Formation until $\sim 92 \mathrm{Ma}$ (Ding et al. 2005; Leier et al. 2007; Zhang et al. 2012a, b) (Fig. 3). The overlying Campanian ( 83-78 Ma) lacustrine-fluvial, and slightly evaporative, units were mainly derived from the south, i.e. the rising Gangdese (Leier et al. 2007). This transition from marine to non-marine is not localised (Sun et al. 2015a, b; Orme and Laskowski 2016) and, coupled with an intense pulse of magmatism at 95-90 Ma (Zhu et al. 2017), suggest that the Gangdese arc exhibited a significant rise in mid-Cretaceous time.

Although the mid-Cretaceous crest height of the Gangdese has not yet been quantified, northward subduction of the Neotethyan oceanic lithosphere formed an 'Andean' type Gangdese range that had reached $\sim 4.5 \pm 0.4 \mathrm{~km}$ high by $56 \mathrm{Ma}$, possibly due to Indian slab break-off (Ding et al. 2014), but surface uplift was confined to the southern margin of the Lhasa terrane. In the northern part of the Lhasa block, the elevation remained low $(\leq 1 \mathrm{~km})$ despite rapid rock uplift between 80 and $70 \mathrm{Ma}$. This was due to fluvial erosion and peneplane formation between 70 and $50 \mathrm{Ma}$ (Haider et al. 2013; Hetzel et al. 2011; Strobl et al. 2012).

The height of the Gangdese mountains appears to have remained above $4.5 \mathrm{~km}$ until the present, although locally there is evidence of $\sim 1-\mathrm{km}$ subsidence since the midMiocene (Saylor et al. 2009; Khan et al. 2014; Ding et al. 2017; Xu et al. 2018) (Fig. 7). Both phytopalaeoaltimetry (plant-based height proxies) and stable isotope palaeoaltimetric proxies consistently yield similar results along the Gangdese mountain chain (Spicer et al. 2003; Currie et al. 2005, 2016; Khan et al. 2014; Ding et al. 2017; Xu et al. 2018) (Fig. 4).

\section{The Qiangtang uplands}

Quantifying the elevation history of these uplands, today's Tangula Mountains (Fig. 1), is more challenging than for the Gangdese because of the continental interior position of the Qiangtang terrane. The continental effect on isotopic composition is complex in this setting and can only be properly resolved using isotope-enabled climate models, but this is only starting to be done. Nevertheless, a quantitative estimate 
Fig. 3 South and Central Tibet in the late Early Cretaceous. The Gangdese formed an elevated land surface at this time, but the crest height, although not yet quantified, is likely to have been $\sim 2 \mathrm{~km}$. The blue arrow illustrates summer air flow drawn northward by an Asian interior low-pressure system and the colour gradations indicate the relative moisture content (dark blue represents wet air and light blue relatively drier air)

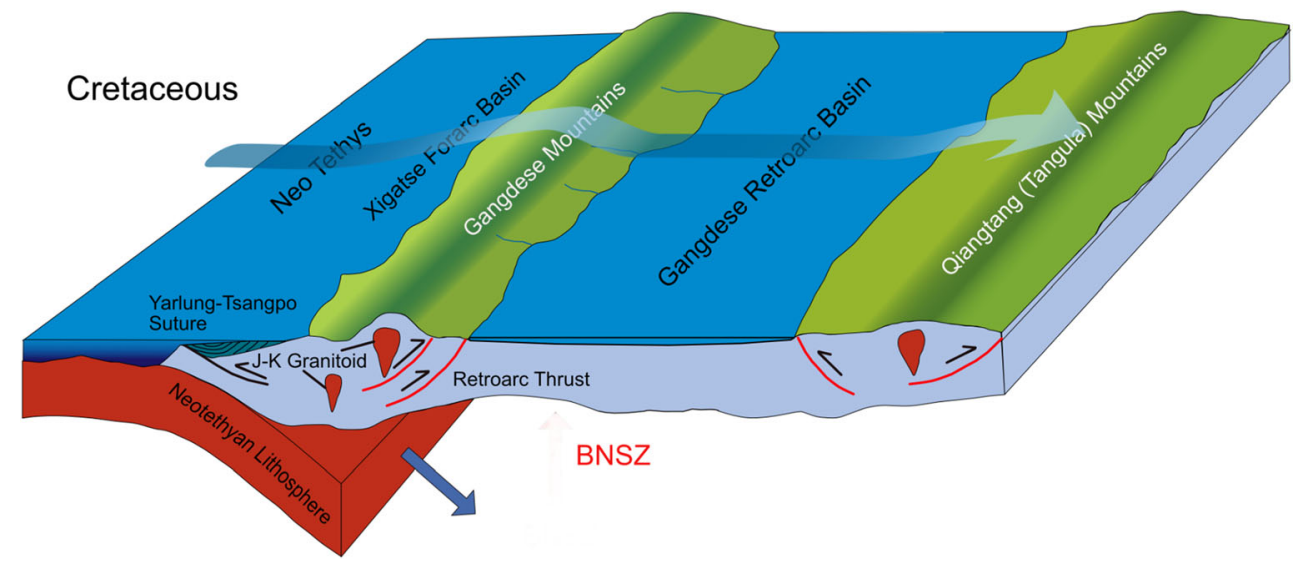

that has been attempted without model-mediation returned an elevation of $\sim 5000 \mathrm{~m}$ at $28 \mathrm{Ma}$ (Xu et al. 2013). It is not possible to say when this elevation was achieved, but the uplands were shedding sediment northwards in the Paleogene as evidenced by sediments in the Hoh-Xil Basin (Wang et al. 2008; Dai et al. 2012), and suggest that large parts of the Qiangtang terrane were already elevated in the Eocene. Very recently, modelling has been used to verify assumptions underlying a height estimate for radiometrically dated sediments within the Gonjo Basin (Fig. 1), which showed a rapid rise of the eastern Qiangtang uplands to $\sim 3.8 \mathrm{~km}$ by $\sim 44$ $40 \mathrm{Ma}$ (Xiong et al. 2020).

\section{Central Tibet in the Paleogene}

Popular orographic models of Tibet typically envisage a palaeo-plateau from the Gangdese northwards across the
BNSZ (England and Houseman 1988; Molnar 1989; Rowley and Currie 2006; DeCelles et al. 2007). This is particularly so for the Proto-Tibetan Plateau model that specifically envisages a 'high and dry' central core of Tibet throughout the Paleogene (DeCelles et al. 2007; Wang et al. 2014). To test these models, it is therefore essential to measure the surface height of the BNSZ over time, but when this has been attempted, different techniques have given markedly different results (Deng and Ding 2015).

Isotope palaeoaltimetry in Central Tibet

Until recently, estimating Cenozoic height changes across central Tibet mostly relied on the use of stable isotopes, with all the additional uncertainties that arise away from the windward slope of a single mountain front. Nevertheless, the 'educated guesses' (Hoke 2018, p. 96) used to minimise these and other uncertainties have routinely suggested late
Fig. 4 Diagram showing the slowdown in the northward convergence of India with respect to Eurasia over time (dotted lines) from Molnar and Stock (2009), and palaeoaltimetry of the southern margin of Tibet as determined by stable isotope palaeoaltimetry and phytopalaeoaltimetry. Modified from Xu et al. (2018)

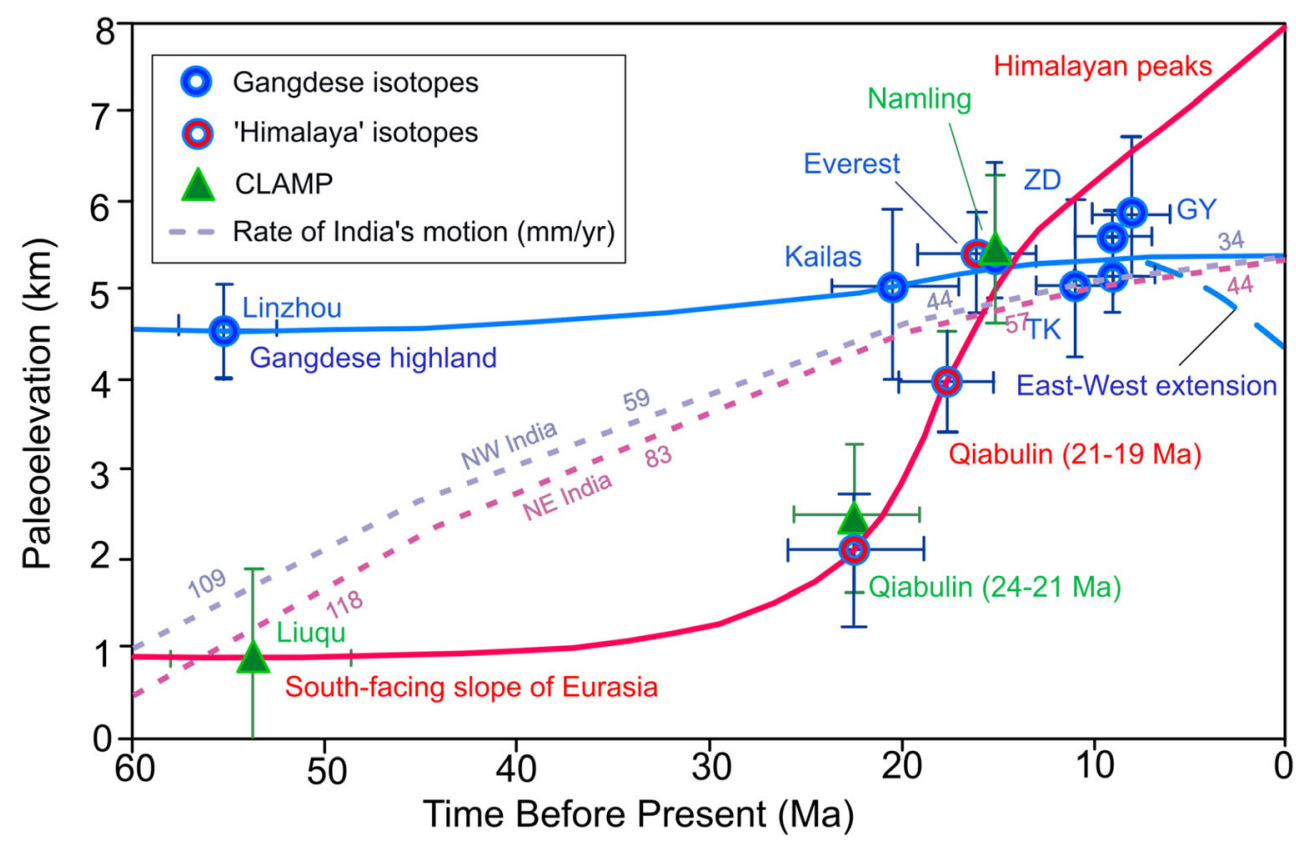


Paleogene BNSZ elevations similar to those of present (> $4 \mathrm{~km}$ ) (Rowley and Currie 2006; DeCelles et al. 2007).

There are several depositional basins preserved along the BNSZ and two, the Nima and Lunpola (Fig. 1), are of particular importance because they yield surface height estimates based on both isotopes and fossils. The successions within these basins are divisible into a predominantly fluvial Paleocene-Eocene Niubao Formation and an overlying 1000-m-thick, predominantly lacustrine, Oligocene-Miocene (25.5-20 Ma) Dingqing Formation (Du et al. 2004; Ma et al. 2015, 2017; Han et al. 2019), with limited age control constrained by radiometrics (He et al. 2012), magnetostratigraphy (Sun et al. 2014a, b), cyclostratigraphy (Ma et al. 2017) and palynology (Wang et al. 1975; Sun et al. 2014a, b). Oxygen isotopes from carbonate palaeosol nodules in the upper Niubao Formation, Lunpola Basin (Fig. 1), yield Late Eocene elevations of $4850 \mathrm{~m}+380 /-460 \mathrm{~m}$, while underlying lacustrine limestones and marls within the same formation yield an elevation of $4050 \mathrm{~m}+510 /-620 \mathrm{~m}$ (Rowley and Currie 2006). Thin-bedded lacustrine marls and limestones of the overlying Oligocene and Miocene Dingqing Formation, still within the Lunpola Basin, also give high mid-Miocene elevations of $4260 \mathrm{~m}+475 /-575 \mathrm{~m}$ (Rowley and Currie 2006). In the nearby Nima Basin (Fig. 1), radiometrically dated soil carbonates give a palaeoelevation estimate of $4.5-5 \mathrm{~km}$ at $26 \mathrm{Ma}$ (late Oligocene) (DeCelles et al. 2007). Deuterium/hydrogen (D/H) ratios in $n$ alkanes derived from leaf waxes also give similar results (3600$4100 \mathrm{~m}$ for the Niubao Formation and 4500-4900 $\mathrm{m}$ for the Dingqing Formation) (Polissar et al. 2009).

Palaeontological evidence for surface height

Fossil finds from the BNSZ basins tell a totally different story and attest to low elevation humid conditions. The BNSZ basins host numerous faunal (insect, fish, mammal), floral (megafossil and pollen/spores) and molecular (biomarker) fossils within a 4-km-thick Cenozoic succession of palaeosols, fluvial, fluvio-deltaic and lacustrine units, some indicative of freshwater and some of saline conditions (Ma et al. 2015, 2017).

\section{Insects}

The fine-grained laminated grey lacustrine units of the Dingqing Formation in the Lunpola Basin (Fig. 1) indicate a long-lived stable lake environment ideal for preserving delicate structures such as those seen in insects, and the find of a water strider, Aquarius lunpolaensis (Fig. 5a, b), suggests a comparatively low elevation at $\sim 25 \mathrm{Ma}$ (Cai et al. 2019). The closest modern relatives are today found at low elevations across parts of Europe, Scandinavia and north Africa (Damgaard 2005).
Fish

In the Nima basin (Fig. 1), numerous fish fossils include Tchunglinius tchangii (Wang and $\mathrm{Wu}$ 2015) dating from 26 to $23.5 \mathrm{Ma}$ (late Oligocene), which is a species also indicative of low elevations. It belongs to the subfamily Cyprininae of the Cyprinidae, which are widely distributed across Asia, Africa, and central and southern Europe. Low-elevation/ warm-climate species have fewer vertebrae than those that live in high, cold environments such as the endemic 'snow carps' (Schizothoracinae, Cyprinidae) of Tibet today. With T. tchangii having only 33 vertebrae, compared with the 4648 of the modern high-elevation snow carps, Wang and $\mathrm{Wu}$ (2015) suggested that in the late Oligocene the Nima Basin must have been at a low elevation. However, factors other than those related to altitude can affect vertebrae number, and several North American cyprinids have just 34 (Coburn 1986) and, lacking a physiological explanation linking vertebrae number and elevation, the use of such a metric as a palaeoaltimeter has been questioned (Renner 2016).

The Nima and Lunpola Basins (Fig. 1) also yield the earliest (by at least $20 \mathrm{Ma}$ ) example of a climbing perch. Eoanabas thibetana (Anabantidae) (Wu et al. 2017) (Fig. 6) from the Chattian (late Oligocene), or possibly earlier, lower Dingqing Formation likewise suggests a low palaeoelevation. Climbing perches are today restricted to tropical lowlands < $1200 \mathrm{~m}$ a.s.l. in South Asia and sub-Saharan Africa, and live in temperatures of $18-30{ }^{\circ} \mathrm{C}$ (www.fishbase.org) (Skelton 2001). Normally living in low oxygen conditions, climbing perches have developed the capacity to breathe air directly, but as a consequence their ability to take in oxygen only from the water is restricted. This means that they cannot survive where lake surfaces become frozen, so are confined to low elevations, and certainly well below the $4 \mathrm{~km}$ or more suggested by the oxygen isotope palaeoaltimetry. Because of this requirement for ice-free lake surfaces, the biomarker interpretation of a cold dry climate in the Lunpola in the lower part of the Dingqing Formation (Cao et al. 2020) is doubtful.

In central Tibet, lowland thermophillous fishes such as E. thibetana and T. tchangii do not persist into the Miocene, but are replaced higher in the Dingqing Formation by Plesioschizothorax microcephalus, a primitive representative of the snow carps that persist today on the Tibetan Plateau. Comparison with living snow carps suggest that $P$. microcephalus was likely to have lived at $\sim 3000 \mathrm{~m}$ after adjusting for secular climate change (Chang et al. 2010), but again this estimate could be challenged as with $T$. tchangii.

\section{Mammals}

The Dingqing Formation fauna has also yielded an early Miocene rhinocerid almost identical to Plesiaceratherium gracile from the lowland early Miocene Shanwang fauna 
in Shandong, eastern China, which according to Deng et al. (2012) limits the elevation to below $\sim 3000 \mathrm{~m}$.

\section{Palynology}

The above elevation estimates used free air thermal lapse rates, qualitatively by implication, to assess palaeoelevation, but in the case of fossil pollen, free air lapse rates have been used quantitatively. The pollen of the Dingqing Formation (Wang et al. 1975; Sun et al. 2014a) represents a peculiar mixture of both cool temperate forms together with more thermophillous taxa typical of subtropical conditions. The succession spanning 25.5 to $19.8 \mathrm{Ma}$ is divisible into three palynological zones, with the winddispersed bisaccate conifer Pinuspollenites dominant in all three zones. Wind-dispersed pollen representing other cool temperate conifers such as Piceapollenites (indicative of spruce trees) and Abiespollenites (firs) co-occur with temperate broadleaved trees represented by Betulaepollenites (birch), Ulmipollenites (elms), Alnipollenites (Alder) and Quercoidites (oaks). However, predominantly tropical to subtropical evergreen broadleaved species such as Castanopsispollenites and Meliaceoidites also occur in the assemblages, and such a mix of taxa with widely diverse thermal tolerances cannot reflect co-occurrence in the source vegetation. Such an ecologically improbable amalgam was most likely formed during transport from disparate growth sites into the lake sediments.

To estimate palaeoelevation, Sun et al. (2014a) used the total palynological assemblage interpreted through the coexistence approach (Mosbrugger and Utescher 1997; Utescher et al. 2014) to obtain a mean annual temperature, together with an Eocene free air lapse rate (Song et al. 2010). The outcome was a palaeoelevation estimate of $3190 \pm 100 \mathrm{~m}$, but by aggregating the whole assemblage, this number represents an elevation somewhere within the altitudinal range occupied by all the vegetation communities contributing to the assemblage; both those high on the mountain sides (cool temperate vegetation) and those growing around the margins of the palaeo-lake occupy the floor of the basin/valley system (the sub-tropical community) (Su et al. 2019). As such, this surface height estimate for the lake margins is likely to be too high, even though it is lower than the isotopes indicate. There is no reliable and objective way to filter the various species contributions to correct for community mixing, but preserved alongside the pollen are plant megafossils, which because of their inherent susceptibility to degradation during pre-burial transport are more likely to reflect vegetation close to their lacustrine site of deposition, even in mountainous regions (Spicer and Wolfe 1987).
Plant megafossils

Plant megafossils from the lower (late Oligocene) Dingqing Formation, which are associated with the climbing perch, include palm leaves named Sabalites tibetensis (Su et al. 2019), leaves of the 'golden rain tree' Koelreuteria lunpolaensis and K. miointegrifolia (Jiang et al. 2019), a Pistacia leaflet, Cedrelospermum tibeticum (Jia et al. 2019), a leaf of Araliaceae, a palmately compound leaf of Handeliodendron sp., with six leaflets, leaves of the water plant Limnobiophyllum pedunculatum (Fig. 5c) (Low et al. 2019), leaves of Exbucklandia sp., Magnoliales, Salix sp., several unidentified toothed and untoothed woody dicot leaves, and the lake margin monocot Typha (Wu et al. 2017) (Fig. 7). The flora as a whole consists of intact leaves and leaflet clusters and shows no sign of long-distance transport, and so represents vegetation growing spatially and altitudinally very close to the lake margin. Qualitatively these taxa represent sub-tropical to warm temperate conditions consistent with those indicated by the associated fish and insect fauna.

Until further collecting is undertaken, the Dingqing leaf flora is not diverse enough to conduct a leaf physiognomic analysis (CLAMP—http://clamp.ibcas.ac.cn). However, of particular interest are the palm remains because palms are intrinsically cold intolerant (Reichgelt et al. 2018), and if the relevant cold month mean terrestrial thermal lapse rate were known, the palms could provide a maximum possible elevation for the basin floor (Su et al. 2019).

Large ( $\sim 1 \mathrm{~m}$ long) fronds of the coryphoid palm Sabalites tibetensis T. Su et Z.K. Zhou (Fig. 7a) have been recovered from the grey finely laminated sediments of the lower Dingqing Formation (Su et al. 2019). By using 13 possible topographic configurations for central Tibet, a General Circulation Model with Chattian boundary conditions showed that palm winter survivability was only possible within a valley, the bottom of which could have been no more than $2.3 \mathrm{~km}$ above sea level. This is almost $3 \mathrm{~km}$ lower than some stable isotope determinations ( $\mathrm{Su}$ et al. 2019). Such a climate modelmediated approach to quantitative palaeoaltimetry avoided the use of an inappropriate mean annual free air lapse rate, using instead the more precise cold month mean temperature terrestrial lapse rate and, by integrating a model with Chattian boundary conditions, secular climate change was automatically compensated for.

Hosting several plant-bearing layers, the underlying middle Eocene (Lutetian) Niubao Formation in the Bangor Basin

Fig. 5 Examples of fossil water striders and a reconstruction of Limnobiophyllum inhabiting the Dingqing Formation lacustrine environment, central Tibet. a, b Aquarius lunpolaensis, $\mathbf{c}$ reconstruction by Fei-Xiang $\mathrm{Wu}$ of the floating aquatic plant Limnobiophyllum pedunculatum 

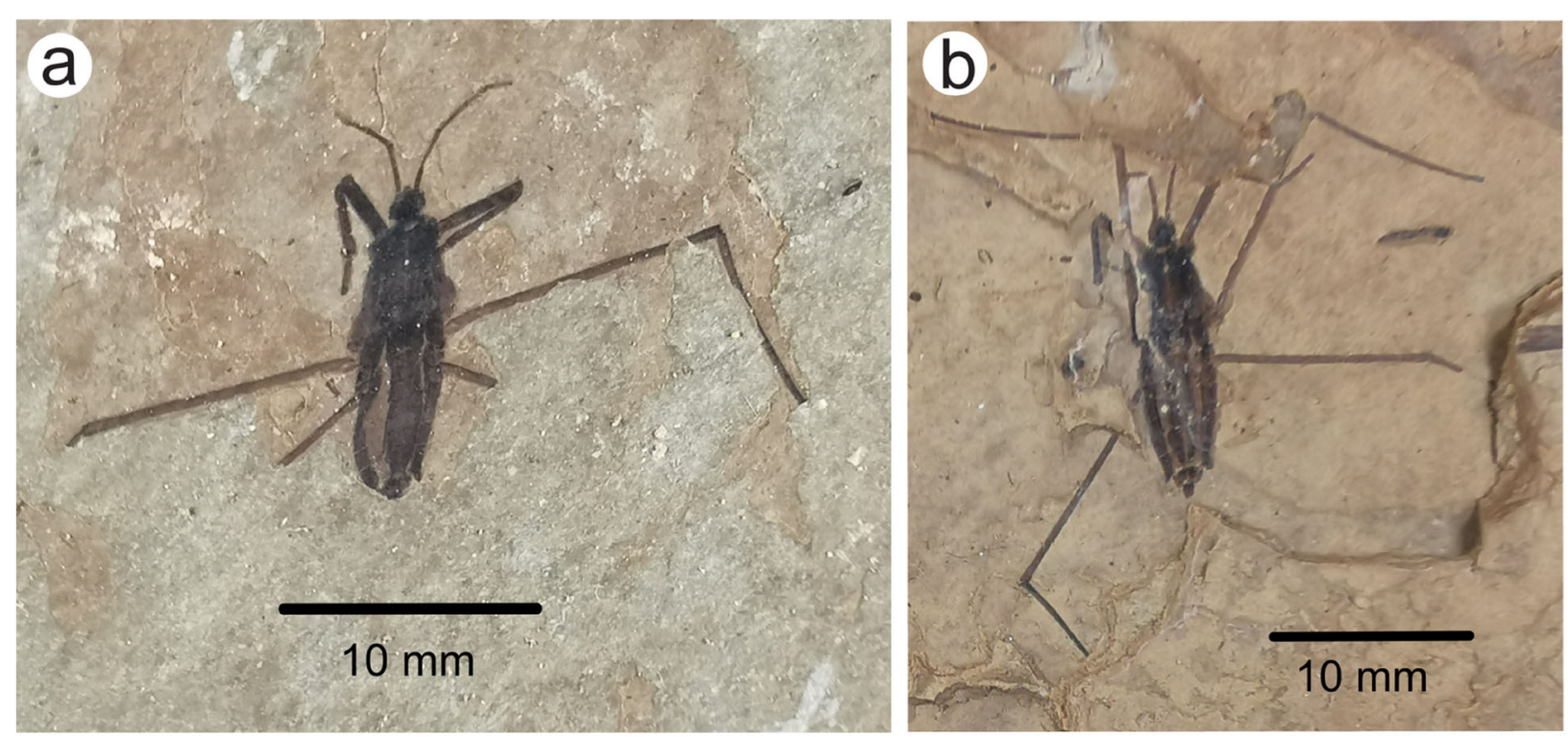

(C)

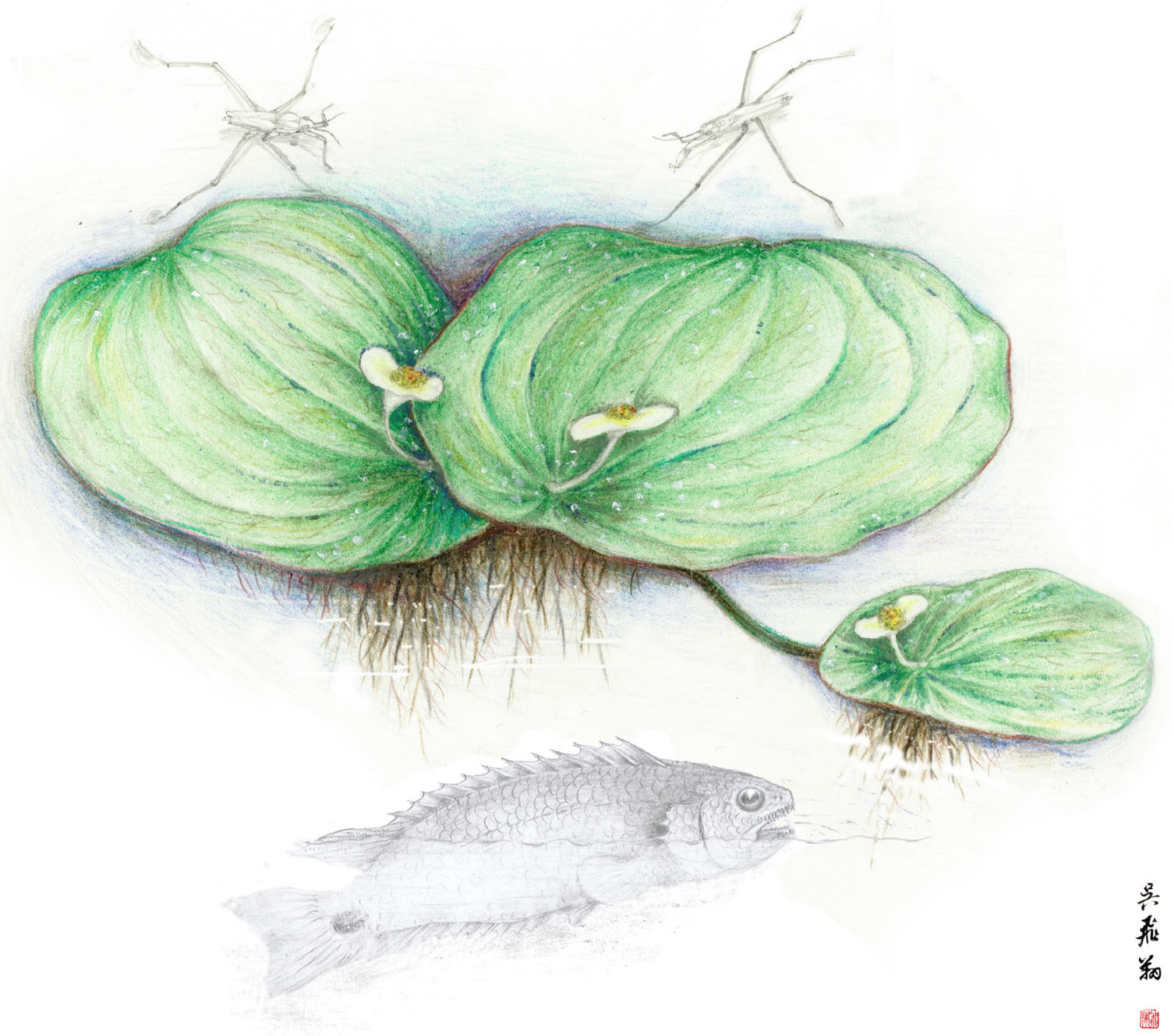



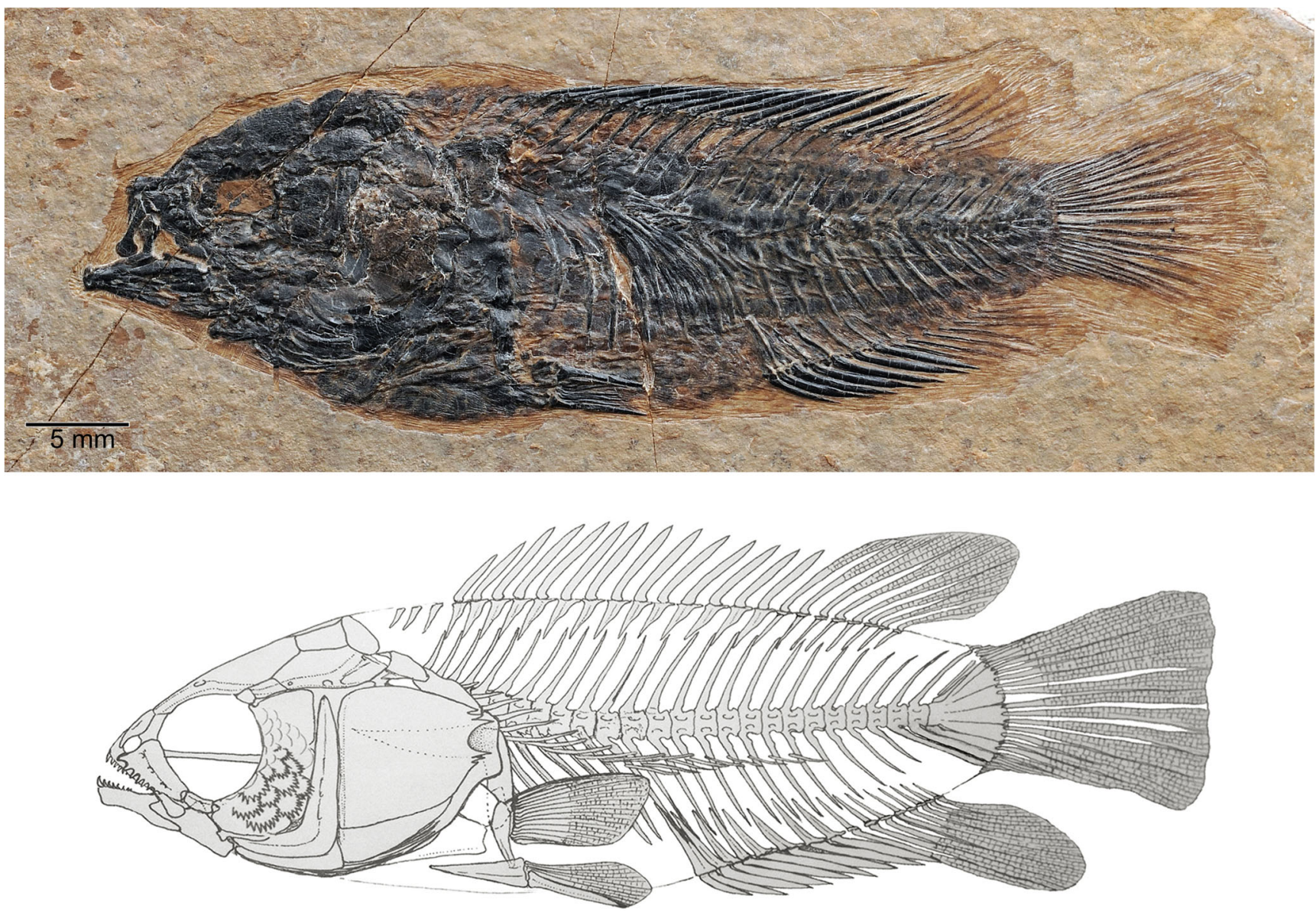

Fig. 6 Specimens of the fossil climbing perch, Eoanabas thibetana. This species is found in the Oligocene lacustrine lower Dingqing Formation sediments of the south Nima and Lunpola Basins (Wu et al. 2017), and

(Fig. 1), near the village of Jianglang, contains a diversity of remains including leaves, fruits and seeds, such as Ailanthus maximus, Asclepiadospermum marginatum, A. ellipticum and Lagokarpos tibetensis (Liu et al. 2019; Tang et al. 2019; Del Rio et al. 2020). These represent low-elevation humid subtropical vegetation with floristic links to the Eocene Green River flora of western USA, and the middle Eocene Messel flora in Germany, as well as other similarly dated assemblages in Africa and the UK (Del Rio et al. 2020), and suggests that a deep central valley existed between the Gangdese and Qiangtang highlands throughout much of the Paleogene (Fig. 8). Figure 9 shows examples of Largokarpos from North America, Germany and the Jianglang flora (Tang et al. 2019).

Lowland thermophilic humid forests in the Paleogene of central Tibet are also evidenced by finds of dipterocarp amber (Wang et al. 2018a), apparently reworked from the Niubao into the Dingqing Formation. Dipterocarps are tropical lowland forest dominants across S. Asia today (Ashton 1982, 2003; Corlett 2019; Morley 2000), but at the time of writing no definitive dipterocarp megafossils have been found, so the existence of dipterocarps in the Paleogene of central Tibet needs to be further investigated. occurs at the same site that yields the palms shown in Fig. 7. Such specimens preserve the specialised air-breathing apparatus seen in modern climbing perches. Drawing by Fei-Xiang Wu. Scale bar represents $5 \mathrm{~mm}$

\section{Reconciling stable isotope and palaeontological palaeoaltimetry}

Stable isotope and palaeontological proxies give highly divergent results in central Tibet, so how can this be reconciled? The first question to answer is: are these two proxies inherently different in terms of calibration? Unfortunately, multiproxy crossvalidation is still rare, but one location that has been intensively studied is the mid-Miocene (15 Ma) Namling-Oiyug Basin (Fig. 1, Table 1) within the Gangdese highland. Here, both well-dated leaf fossils and lacustrine/palaeosol carbonates have been examined from a palaeoaltimetric perspective using foliar physiognomy, oxygen and $\mathrm{D} / \mathrm{H}$ ratio isotope systems.

The first quantitative height determination in the basin used an early version of CLAMP to derive palaeo-moist enthalpy from the Namling flora; a leaf assemblage from predominantly lacustrine sediments exposed within a single inclined horizon spanning modern elevation of 4300-4700 m (Spicer et al. 2003). Compositionally, this flora represents cool temperate vegetation with strong affinities to taxa found today in Yunnan, Sichuan, the Himalaya and northern China (Guo et al. 2019), and is indicative of high elevations. Because 

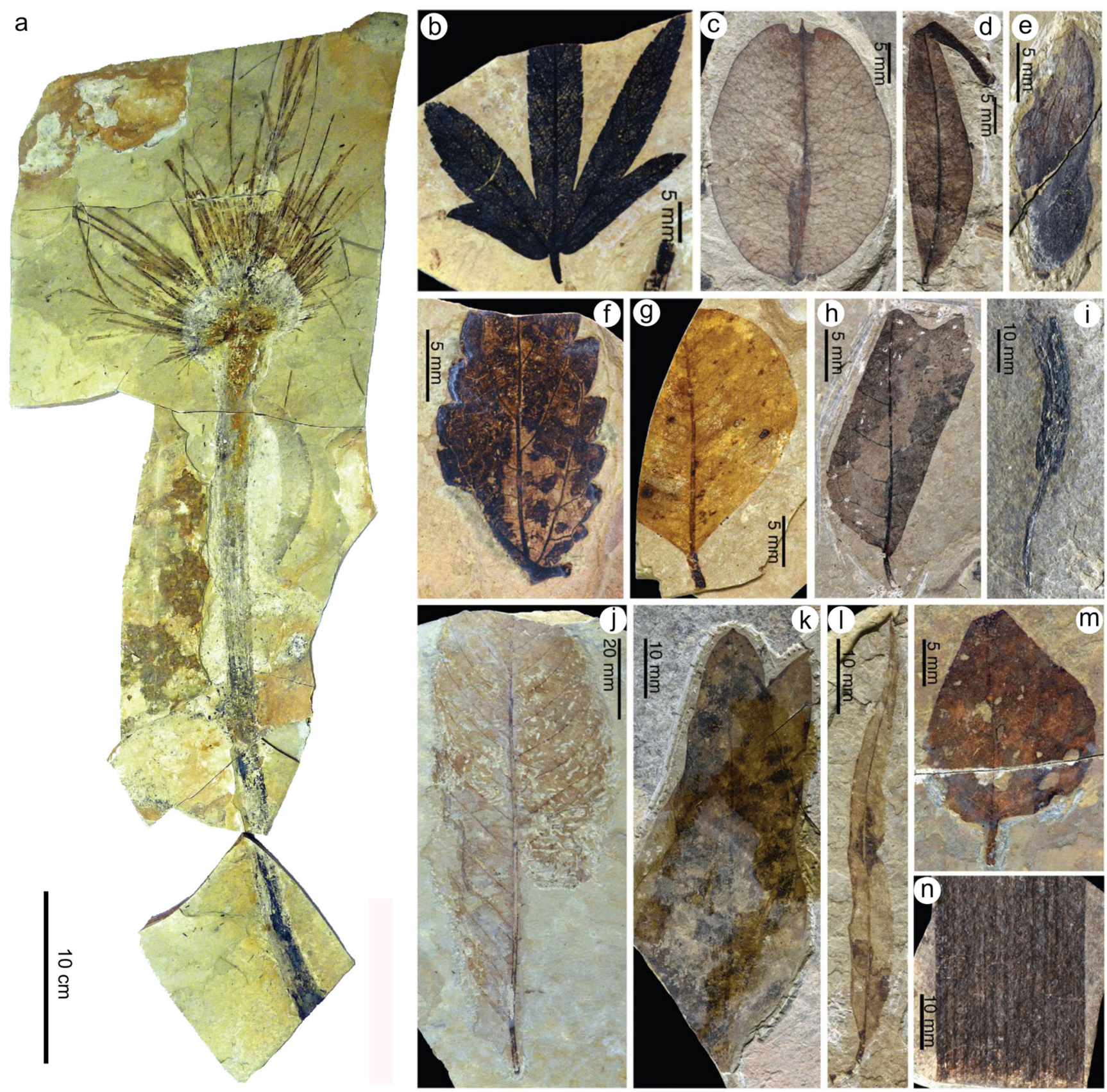

Fig. 7 Illustrations of representative plant fossils of the Dingqing flora, modified from $\mathrm{Wu}$ et al. (2017) and $\mathrm{Su}$ et al. (2019). a A frond of Sabalites tibetensis T. Su et Z.K. Zhou (Su et al. 2019); b compound leaf of Araliaceae; c Koelreuteria sp. (golden rain tree); d Pistacia leaflet; e winged fruit of Cedrelospermum sp.; f unidentified toothed leaf; $\mathbf{g}$

unidentified entire-margined leaf; $\mathbf{h}$ unidentified toothed leaf; $\mathbf{i}$ infructescence of probable Araceae; $\mathbf{j}$ leaf of Magnoliales; $\mathbf{k}$ unidentified entire-margined leaf; $\mathbf{I}$ Salix sp.; $\mathbf{m}$ unidentified entire-margined leaf; $\mathbf{n}$ fragment of Typha leaf

suitably diverse proximal contemporaneous sea-level floras were not available at the time of the original study, a constrained climate model was used to provide the required moist enthalpy datum from which a palaeoelevation of 4689 $\pm 895 \mathrm{~m}$ was obtained. Subsequently, this was revised to 5260-5540 m using a calibration more suited to Asia, and a near sea level datum from a similar-aged flora (Kameng River, Fig. 1 and Table 1) in the Siwaliks, NE India, but climate model mediation was still used to correct for palaeolatitude
(Khan et al. 2014). This high surface height measurement is indistinguishable from an elevation of $5200+1370 /-606 \mathrm{~m}$ obtained using oxygen isotopes in carbonates at the same location (Currie et al. 2005) and the Rayleigh fractionation model. It is also the same as a value of $5100+1300 /-1900 \mathrm{~m}$ subsequently obtained using hydrogen isotopes from leaf waxes (Currie et al. 2016). This congruency shows that all three methods are similarly calibrated, so the disparities in central Tibet must be due to other factors. 

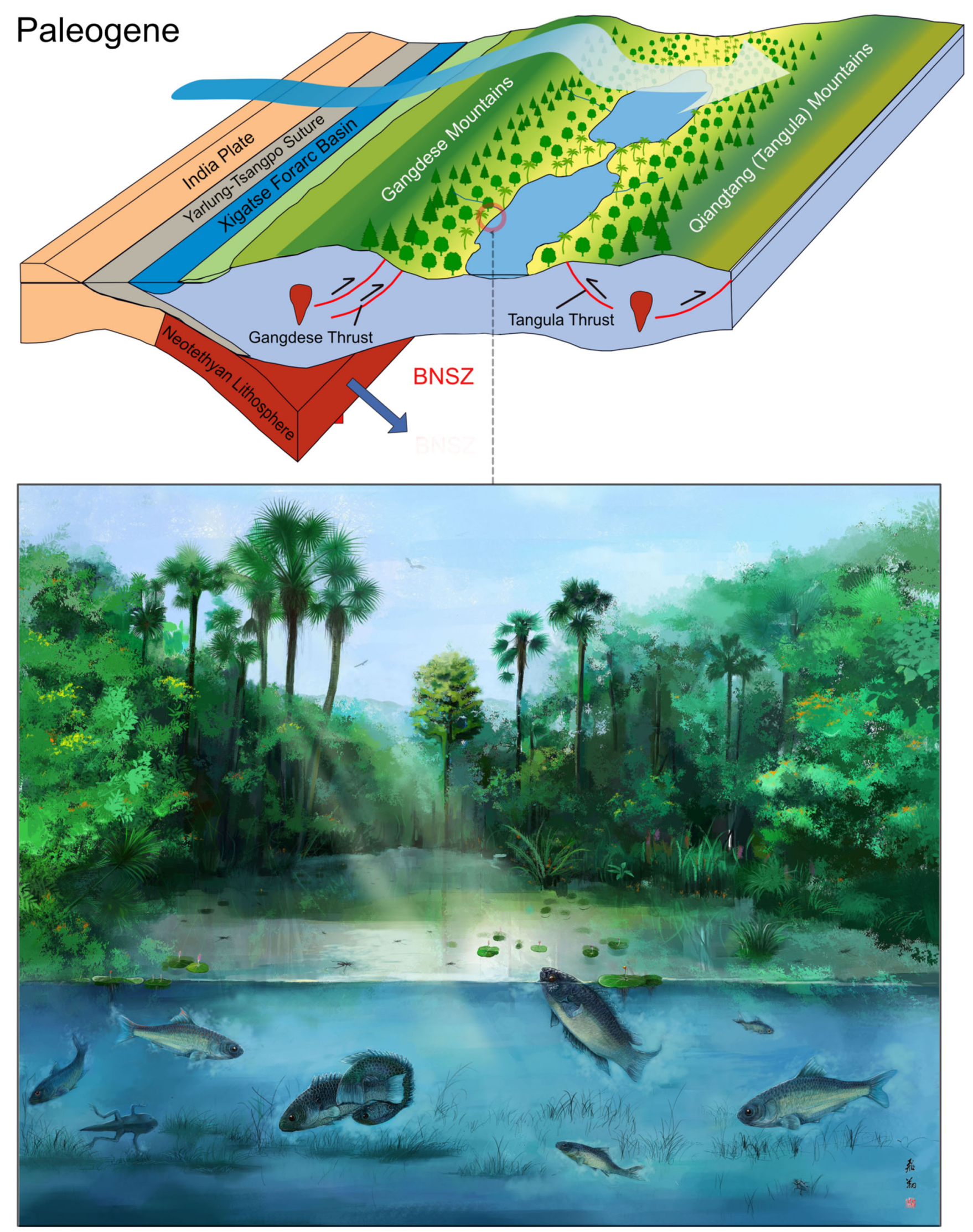
Fig. 8 Cartoon showing southern and central Tibet in the Paleogene. Lowland vegetation was characterised by sub-tropical taxa, including palms as shown in the inset reconstruction, along with a diverse fauna that included the climbing perch Eoanabas thibetana. Higher on the mountainsides, cool temperate coniferous vegetation predominated. Lake level was below $2 \mathrm{~km}$, while the Gangdese and Qiangtang uplands exceeded $4.5 \mathrm{~km}$. The blue graded arrow indicates summer airflow becoming drier as it passes over the Gangdese highlands. Reconstruction by Fei-Xiang Wu

Figure 10 illustrates why stable isotopes may give a falsely high estimate of elevation across a valley system, in this case along the Paleogene BNSZ, which then inevitably appears as a plateau. In the case of Tibet, a predominant Indian Ocean source to the south leads to moisture-laden winds encountering the E-W Gangdese mountain system. As moist air is forced upwards and cools, heavy isotopes preferentially rain out, leaving only moisture enriched with light isotopes to crest the mountain tops and move downslope (Deng and Jia 2018), adiabatically warming, into the valley to the north. Water entering the valley lake system by mountain streams on the leeward side of the mountains would also be depleted in the heavy isotopes. In winter, drier air moving southwards from a deep Asian interior (Siberian) low, and passing over the Qiangtang mountains, will also have a depleted heavy isotope content. This means that overall, the valley system will be isotopically light and therefore yield a 'phantom' high elevation more indicative of the height of the mountain crests bounding the valley than the valley lowlands. This effect is also shown by isotope-enabled computer models (Fig. 11). In model simulations where the western end of the BNSZ valley is open, a small amount of moisture penetrates on westerlies from the retreating Paratethys Ocean, but the proportion of heavy isotopes this introduces is insufficient to lower the apparent 'phantom' high plateau because the dominant moisture supply is via summer southerlies.

\section{Northern Tibet}

Stable isotope palaeoaltimetry studies seem to suggest that the Qaidam Basin, currently at an elevation of between 2.8 and $3.2 \mathrm{~km}$, was apparently low in the Paleogene, and only became elevated in the Miocene (Kent-Corson et al. 2009; Li et al. 2016). However, there is ample evidence that parts of northern Tibet rose much earlier, e.g. areas near the Xining (Dupont-Nivet et al. 2007, 2008; Garzione 2008), Qaidam and Tarim Basins (Graham et al. 2005; Bershaw et al. 2012; Kent-Corson et al. 2009). A new discovery of a cool temperate, predominantly deciduous, early Oligocene flora (Fig. 12) in the northern Qaidam Basin also supports that view (Song et al. 2020), as well as some leaf wax hydrogen isotope results from the radiometrically dated sediments on the Hoh-Xil Basin (Lin et al. 2020). However, until the Hoh-Xil Basin results are evaluated using isotope-enabled climate models, they must be regarded as speculative because of unknowns regarding the source waters, air parcel trajectories and the 'continental effect'.

The age of this new Qaidam flora (Fig. 1) is obviously crucial in any discussion of the timing of uplift in this region. The flora comes from the lower member of the $\sim 1500-\mathrm{m}-$ thick Shangganchaigou Formation and is dated as $\sim 30.8 \mathrm{Ma}$ (Rupelian) based on a high-resolution magnetostratigraphic study (Ji et al. 2017) of a long continuous section. The magnetostratigraphy spans what is known as the Dahonggou section, and is constrained by a detailed study of the ostracod assemblage succession in the section: a distinct shift in ostracod assemblages from freshwater Ilyocypris to brackish-water Cyprideis, as well as mammal fossils (Trilophodon). This section exposes, from oldest to youngest, the Lulehe Formation (Fm.), the base of which is dated as $\sim 52 \mathrm{Ma}$, the Xiaganchaigou Fm., the Shangganchaigou Fm., the Xiayoushashan Fm., the Shangyoushashan Fm. and the Shizigou Fm., the top of which is dated as $\sim 7 \mathrm{Ma}$ (Ji et al. 2017). This dating framework is consistent with that of the nearby Hongliugou section (Fang et al. 2019) in which the age of the Shangganchaigou Formation is also well constrained by
Fig. 9 Examples of Lagokarpos from the Eocene of a North America; b Messel, Germany; c Jianglang flora, central Tibet; $\mathbf{d}$ reconstruction of Largokarpos. Scale bar represents $5 \mathrm{~mm}$
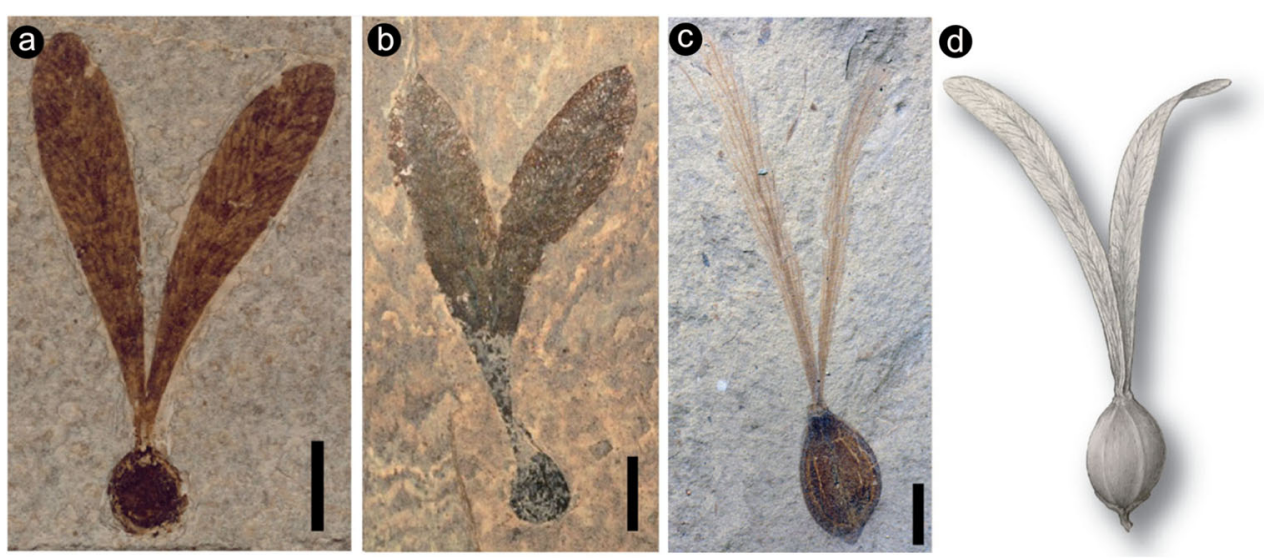


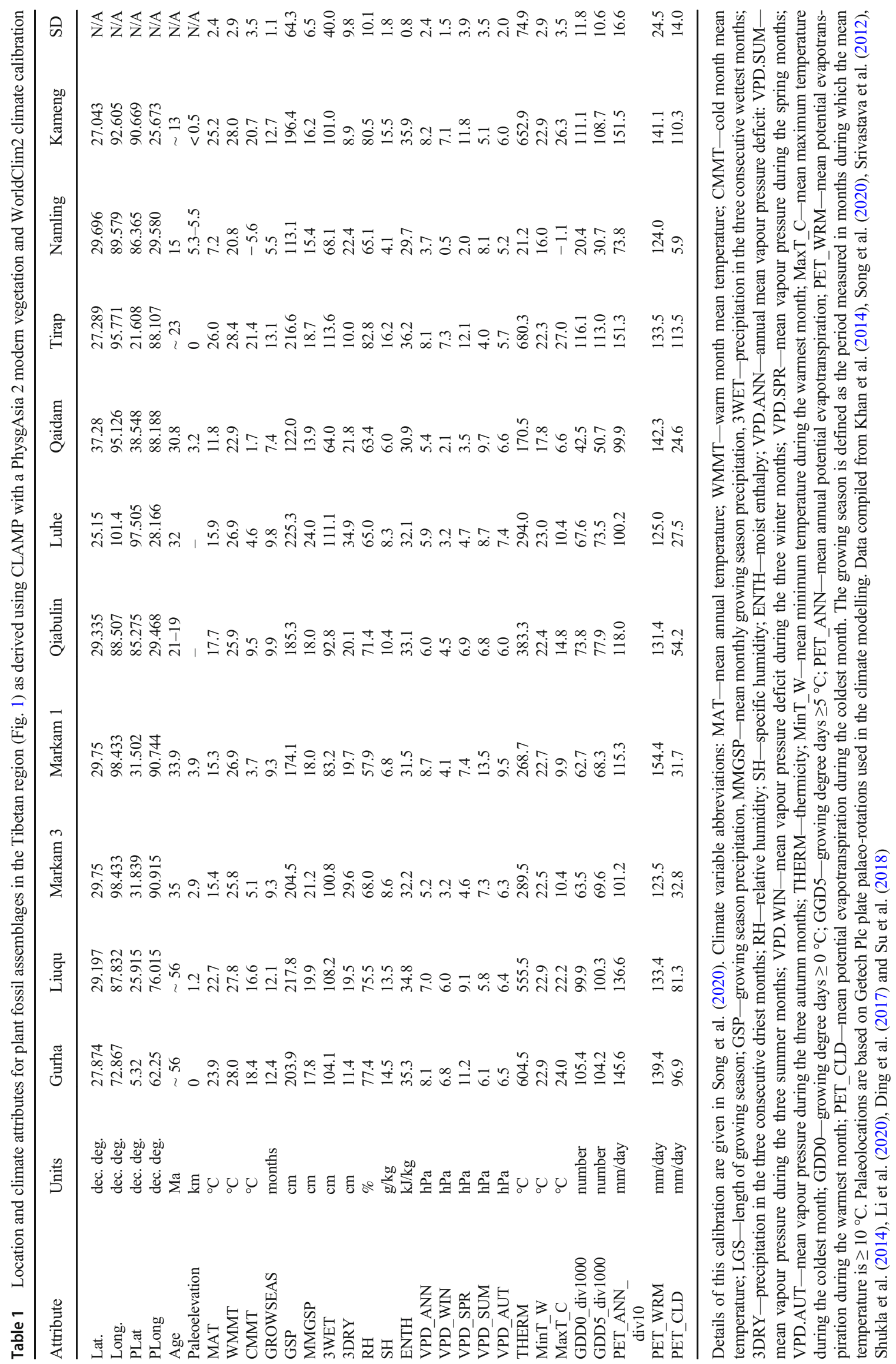




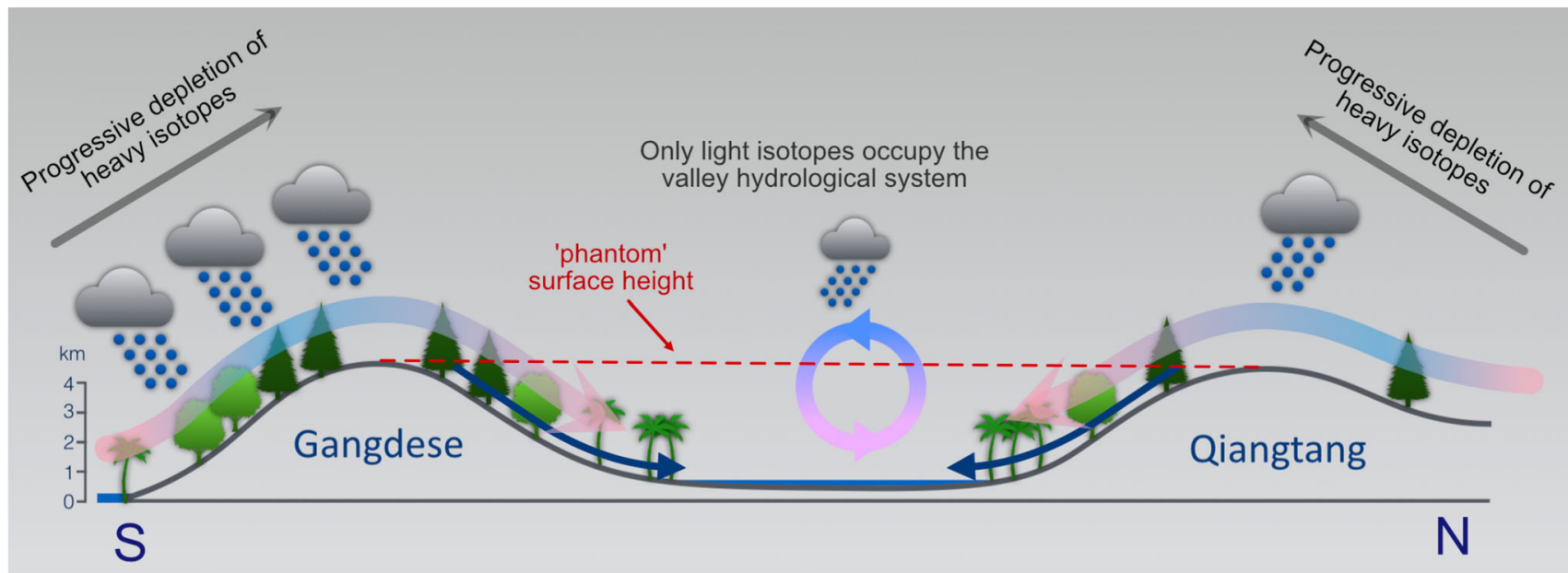

Fig. 10 Diagrammatic explanation of why isotope analysis results in a phantom elevated surface height for the lowlands of the Paleogene central Tibetan valley. In summer, moist air from the south rises against the Gangdese highlands preferentially precipitating out heavy isotopes leaving only isotopically light water to crest the mountain ridge and enter the semi-enclosed valley hydrological system. In winter, drier air,

mammal fossils and magnetostratigraphy, while the Eocene age of the Lulehe Formation matches the cooling ages, as indicated by independent thermochronological dating in the surrounding mountains (Zhuang et al. 2018; Cheng et al. 2019). A younger age for the Lulehe Formation proposed by Wang et al. (2017b) was not adopted by Song et al. (2020) because the chronology of Wang et al. (2017b) is in conflict with other regional chronostratigraphic schemes, and Cenozoic source-to-sink provenance studies for the basin (for a detailed discussion see Song et al. 2019, 2020).

Using a Rupelian (33.9-27.82 Ma) climate model to determine sea level moist enthalpy, coupled with a CLAMPderived moist enthalpy measurement from the Qaidam flora (Table 1), resulted in a palaeoelevation of $3.2 \pm 1.4 \mathrm{~km}$ for the lakeside vegetation, which is indistinguishable from that of the present elevation. It follows that either there was an Eocene uplift of the region or an upland derived from preCenozoic terrane collisions already existed in the Eocene. An Eocene rise is consistent with thermochronological studies that indicate an Eocene exhumation/cooling in the nearby Beishan mountains (Cheng et al. 2016; Qi et al. 2016; Zhuang et al. 2018), as well as numerous Eocene cooling ages derived from detrital thermochronological studies from the Qaidam Basin (Guan and Jian 2013; Wang et al. 2015; Du et al. 2018; Jian et al. 2018), Subei Basin (Li et al. 2017a), Jiuquan Basin (He et al. 2017) and Lanzhou Basin (Wang et al. 2017c). Irrespective of whether the area rose in the Eocene, or much earlier, this high landscape in northern Tibet preceded the rise of the Himalaya. Taken together with the Paleogene rise of other areas of northern Tibet (DupontNivet et al. 2008), it suggests significant 'far field' deformation and uplift in northern Tibet, seemingly simultaneously which is already isotopically light because of continental interior source, is derived predominantly from the north and has to pass over the Qiangtang highlands before it too enters the internally drained valley. Consequently, only isotopically light water is preserved in the valley as organics or carbonates, resulting in a surface height estimate reflecting of the height of the mountain crests bounding the valley

with eastward extrusion of Tibet and the building of the Hengduan mountains.

\section{Eastern Tibet and the Hengduan Mountains}

The modern SE Tibetan Plateau consists of several continental fragments. These include parts of the Lhasa, Qiangtang, Songpan-Ganzi and Yangzte terranes, the Yidun arc, and the Tengchong, Baoshan and Lanaping-Simao terranes (Burchfiel and Chen 2012). A significant proportion of N-S shortening under compression from the India collision was likely to have been accommodated by extrusion of some of these fragments in a semi-rigid manner to the east and south-east (Leloup et al. 1995; Tapponnier et al. 2001; Wang et al. 2016; Li et al. 2017b) along several thousands of kilometres of strike-slip faults within the SE margin of Tibet, including the Ailaoshan-Red River Shear Zone, Chongshan Shear Zone and Gaoligong Shear Zone (Searle 2006; Li et al. 2017b). This could have occurred early in the India-Asian collisional process (Spurlin et al. 2005; Ding et al. 2007), but the low-relief, high-elevation topography has also been used as evidence for ductile flow of the lower crust into the SE margin of the Tibetan Plateau in the Miocene (Royden et al. 1997; Clark and Royden 2000). However, this interpretation depends crucially on a reliable regional dating framework as we discuss below.

A modification of the brittle model envisages extrusion, translation to the south and rotation of the Indo-China block. Based on palaeomagnetic analysis, Tong et al. (2017) argue that since the late Eocene the Lhasa and Qiangtang terranes have not experienced enough crustal shortening to have driven the southward extrusion of SE Tibet. Instead, they suggest the 
a
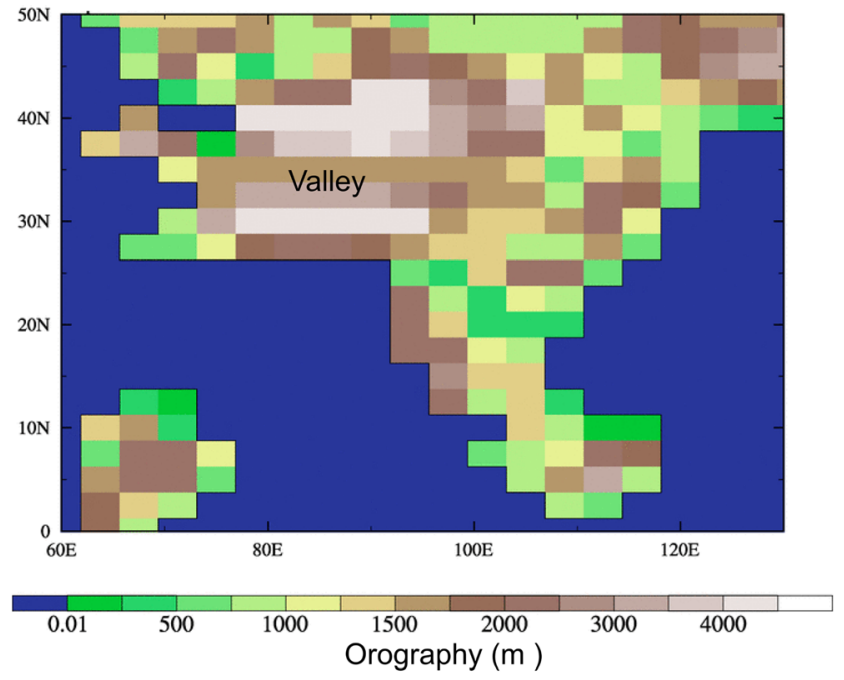

C

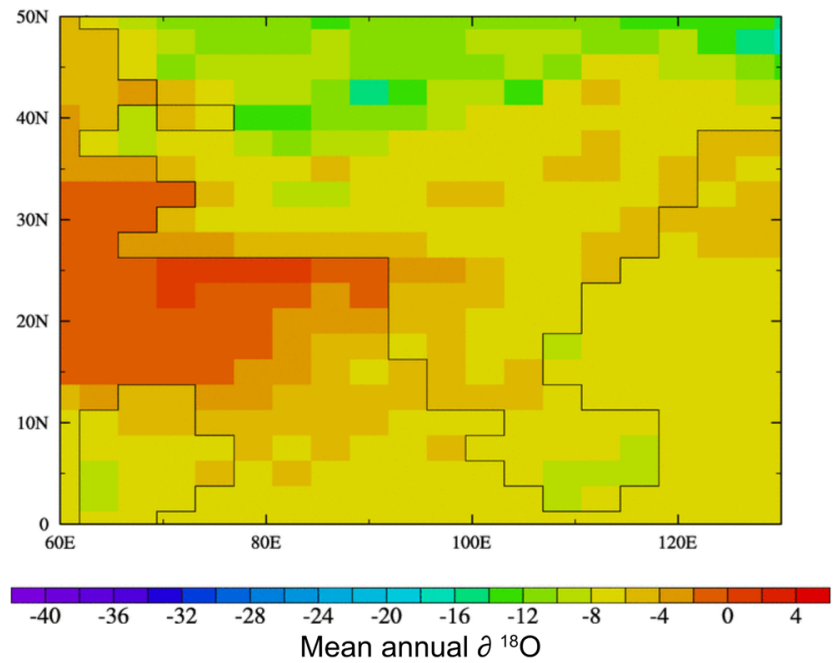

Fig. 11 Maps showing the results of an isotope-enabled experiment we have conducted using Lutetian boundary conditions, illustrating the lack of a clear isotopic signature when a valley is present in central Tibet. a South Asia orography with a deep central valley positioned at $35^{\circ} \mathrm{N}$, b

displacement of the Indo-China block, which was located to the north of the Qiangtang terrane until $\sim 43 \mathrm{Ma}$ (Fig. 13). The displacement would have involved as much as $600 \mathrm{~km}$ of extrusion, and rotation and deformation of the Indo-China block (Li et al. 2017a, b).

If the crustal processes driving the uplift of SE Tibet are unclear, so is the timing of its rise. Based on low-temperature thermochronological studies, a multi-phased rapid uplift of SE Tibet, starting as early as the Late Cretaceous (Wang et al. 2012, 2018a, b; Liu-Zheng et al. 2018; Cao et al. 2019), has been suggested. However, until recently the timing most widely favoured has been a predominantly Miocene uplift of the region based on river incision measurements (Clark and Royden 2000; Clark et al.

\section{b}
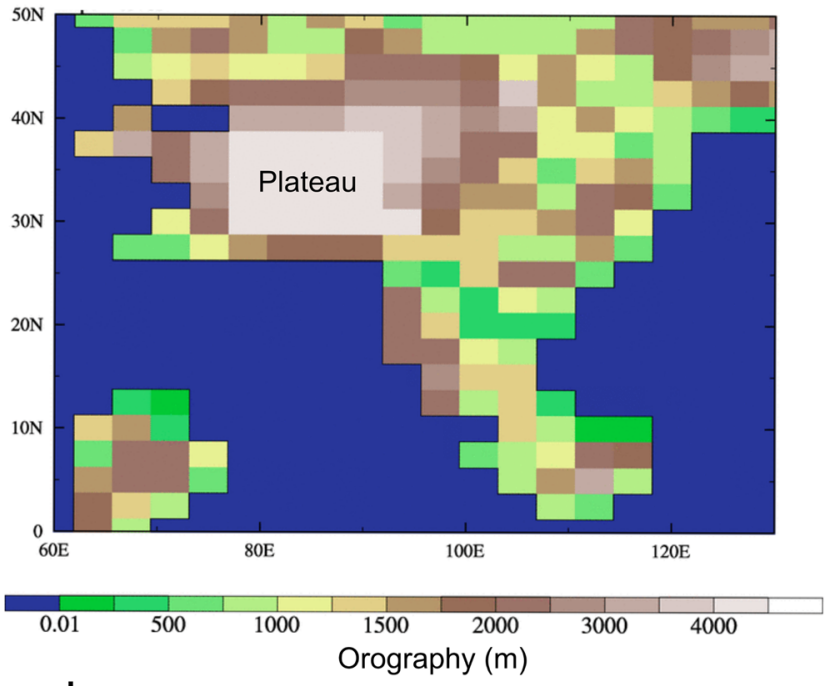

d

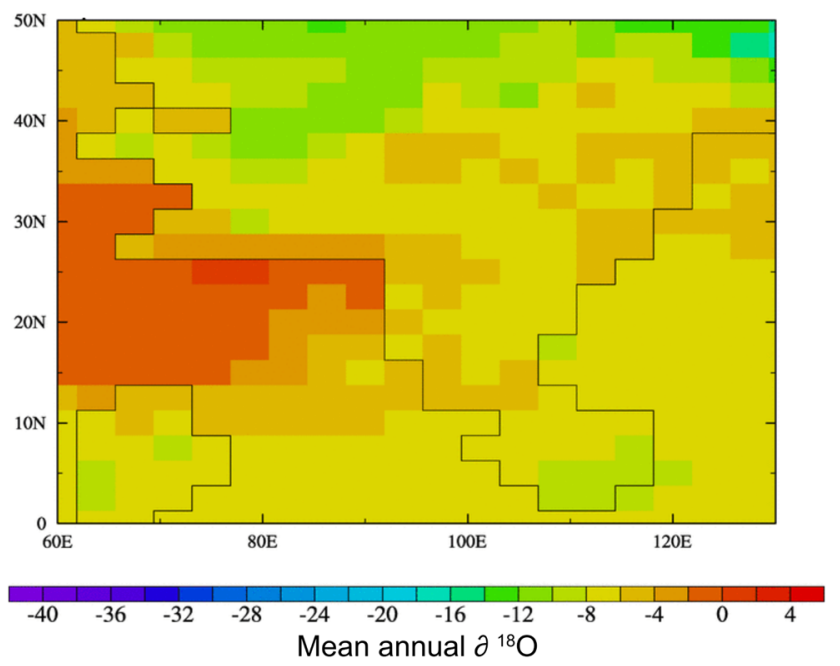

similar to (a) but with a high plateau, $\mathbf{c}$ stable oxygen isotope map with a deep valley as in (a), $\mathbf{d}$ stable isotope map for the plateau scenario as in (b). The valley is not discernible in (c) where the isotopic map is similar to that for a plateau $(\mathbf{d})$
2004). Raising of land surfaces results in river incision and reorganisation of drainages, and rapid incision of major river systems across eastern Tibet and the Hengduan mountains is estimated to have taken place between 15 and $10 \mathrm{Ma}$, a phenomenon used to support the argument for lower crustal flow (Clark et al. 2005; Ouimet et al. 2010). However, an intensification of monsoon rainfall at around this time (Farnsworth et al. 2019) could also have increased incision rates (Nie et al. 2018), and so incision alone is not definitive evidence of uplift. Nevertheless, Eocene to Miocene provenance shifts also took place (e.g. Clark et al. 2004; Clift et al. 2006, 2020; Yan et al. 2012; Wissink et al. 2016), but interpreting these data correctly depends on a reliable regional dating framework. 


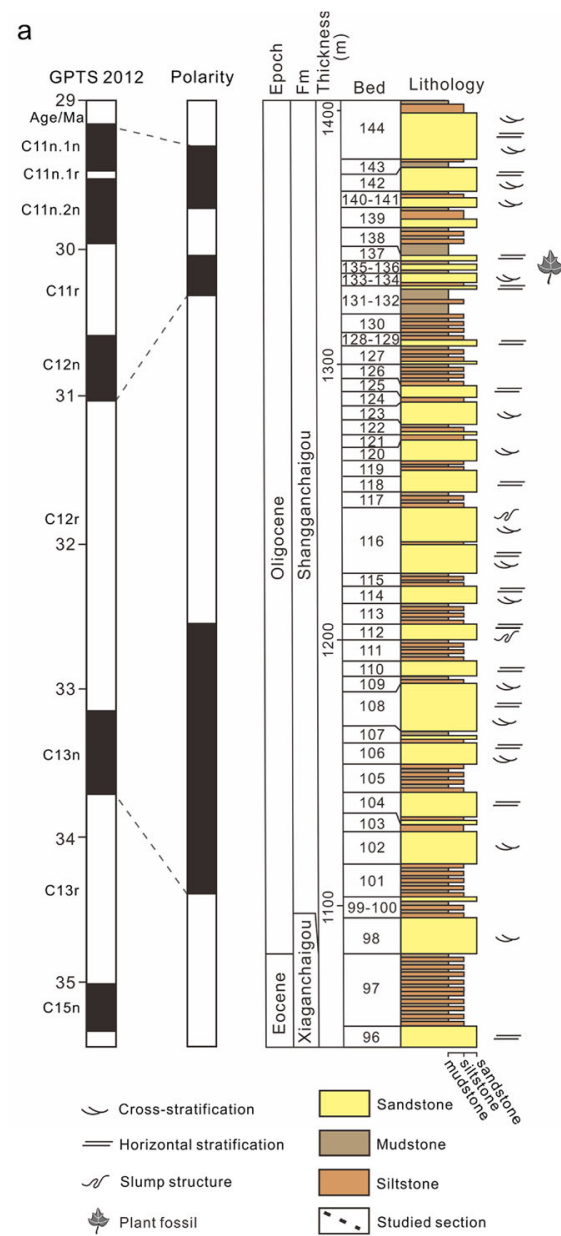

Fig. 12 a Stratigraphic column of the section that preserves the plant fossils illustrated in (b)-(z), modified from Song et al. (2020). This is located in the lower member of Shangganchaigou Formation of the Dahonggou section, northern Qaidam Basin. Shown is the magnetostratigraphic correlation, the chronology and the lithology of the studied section, as well as the chronologic and stratigraphic position

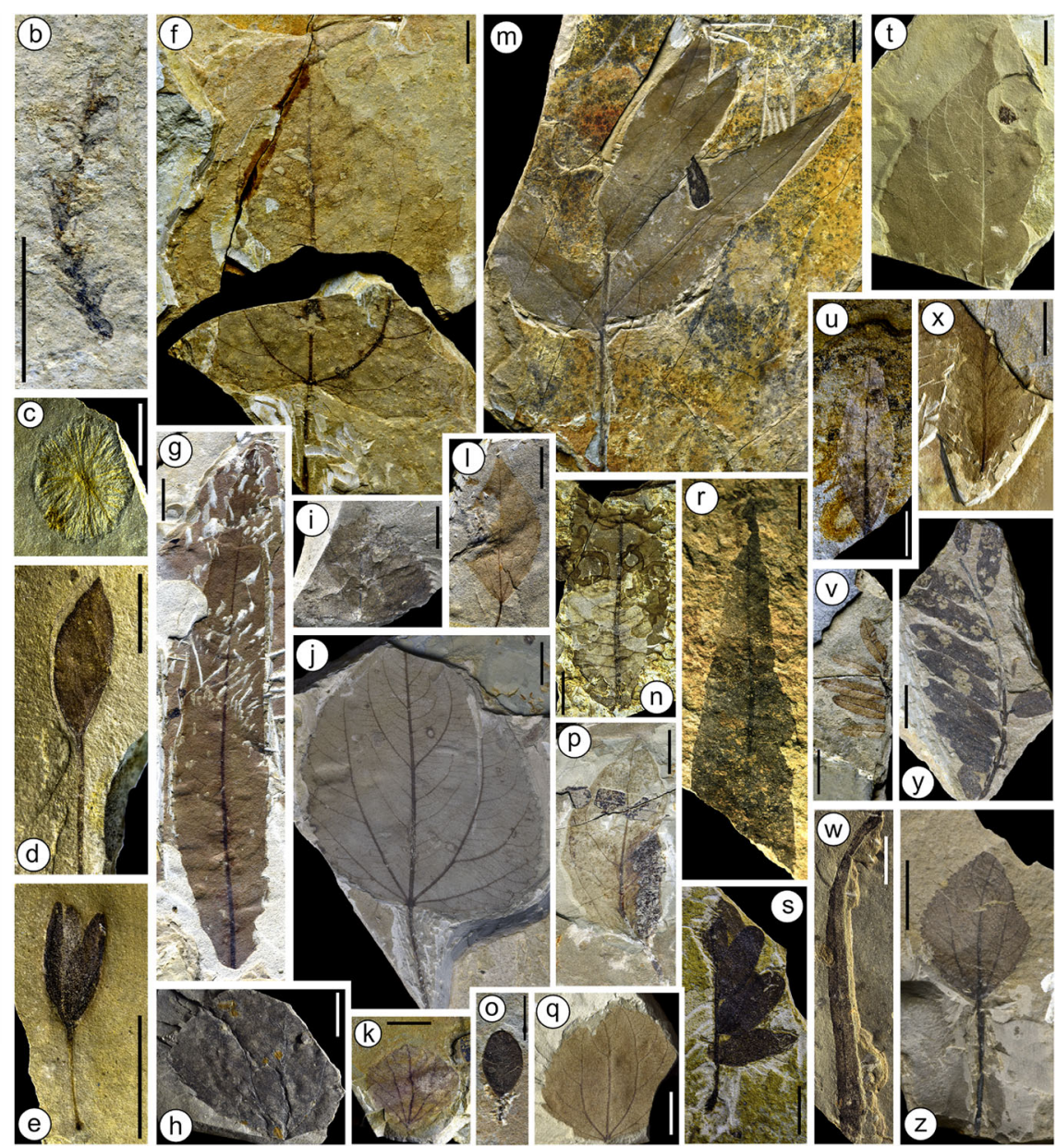

of the plant fossil locality. $\mathbf{b}-\mathbf{z}$ Early Oligocene Qaidam plant fossils, modified from Song et al. (2020). All scale bars $=1 \mathrm{~cm}$. b Leafy shoot of Glyptostrobus; c fruit of Cyclocarya; d single-seeded pod of Podocarpium; e fruit of Populus; $\mathbf{f}-\mathbf{z}$ representative specimens of the 21 morphotypes of woody dicot leaves

assumed a Miocene age were revised from $2.6 \mathrm{~km}$ (Hoke et al. 2014) down to $1.2 \pm 1.2 \mathrm{~km}$ (Gourbet et al. 2017), while subsequent more detailed re-analysis using both isotopic and pollen analysis revised the elevation a third time to be $1.3-2.6 \mathrm{~km}$ in the Eocene. Although lower than now, this estimate suggests some uplift long before the Miocene.

The discovery of a primary (i.e. not detrital) ash bed in the Lühe Basin (Fig. 1) with a zircon U-Pb age of $33 \pm 1 \mathrm{Ma}$, and additional overlying ash beds dated as $\sim 32 \pm 1 \mathrm{Ma}$ (Linnemann et al. 2018), has led to a major re-appraisal of the age of regional floras. These dates showed beyond doubt that the associated 'Miocene' flora was some 20 million years older than previously thought based on the modern aspect of the component leaves, seeds and pollen (Zhang et al. 2007; Xu et al. 2008; Huang et al. 2016; Tang et al. 2020). Further finds of ashes near the base of the nearby Luhe coal mine have yielded ${ }^{40} \mathrm{Ar} /{ }^{39} \mathrm{Ar}$ ages for biotites and feldspars of $\sim 33 \mathrm{Ma}$ (Li et al. 2020), and thus match the U-Pb dates obtained by all late Eocene in age. Earlier palaeoelevation estimates that 
Fig. 13 Extrusion of the IndoChina block based on Tong et al. (2017). Palaeolatitude is only approximate

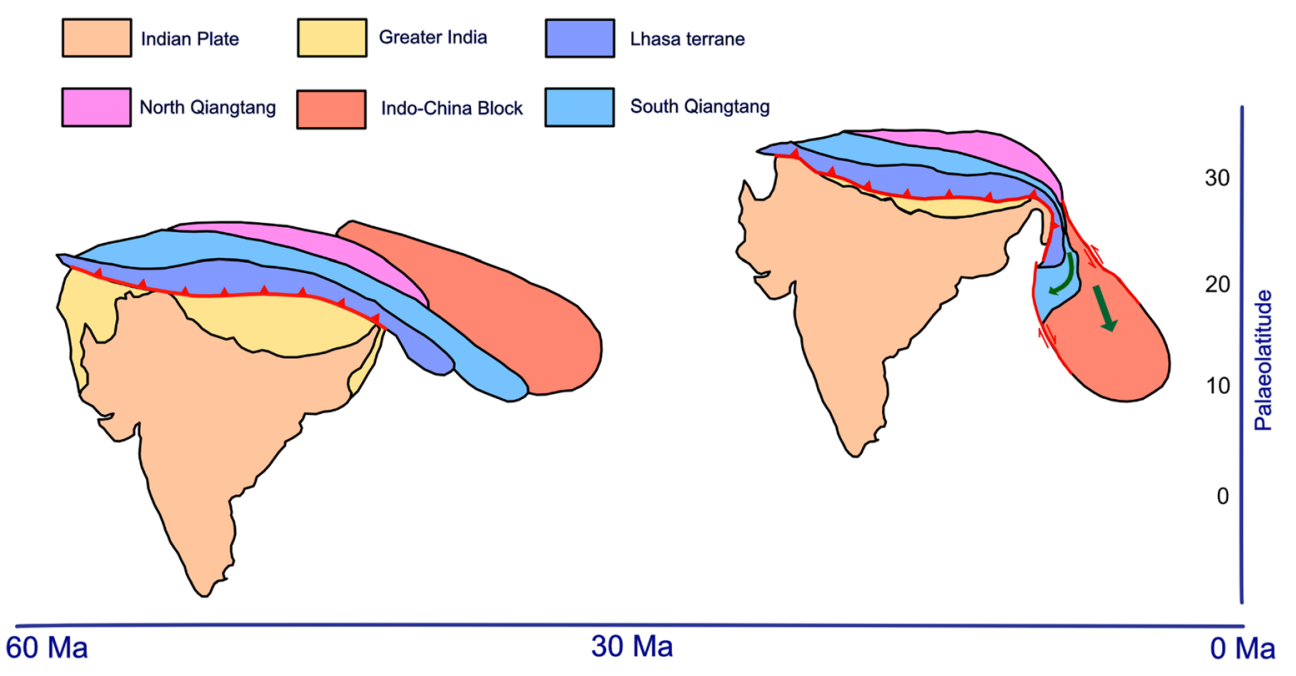

Linnemann et al. (2018) and those of detrital zircons found in fluvial sands higher within the mine section (Wissink et al. 2016). Coupled with palaeomagnetostratigraphy, these ages suggest the Lühe Basin evolved between $\sim 35$ and 26.5 Ma, and constrain the onset of movement of the basin-bounding Chuxiong fault to $35 \mathrm{Ma}$ ( $\mathrm{Li}$ et al. 2020). This demonstrates that the onset of fault movement was contemporaneous with initiation of the Ailaoshan-Red River fault system (Tapponnier et al. 1990; Leloup et al. 1995; Cao et al. 2011) and suggests a common, region-wide, cause.

Radiometric re-dating of 'Miocene' floras has also led to a re-evaluation of topographic development further north on the eastern margin of Tibet. The Mankang (Markam) Basin (Fig. 1) previously thought to have formed in the Miocene (Tao and Du 1987; B.G.M.R. 1991; Su et al. 2014) is now known to host sediments and fossil plant assemblages that span the Eocene-Oligocene (E-O) boundary ( $\mathrm{Su}$ et al. 2018). A lower assemblage here called Markam 3, bounded by volcaniclastics that yield ${ }^{40} \mathrm{Ar} /{ }^{39} \mathrm{Ar}$ ages of $35.5 \pm 0.3$ below and 34.61 $\pm 0.8 \mathrm{Ma}$ above (latest Eocene), represents evergreen and deciduous mixed sub-tropical to warm temperate (Table 1) vegetation. An overlying assemblage (Markam 1) is also bounded by volcaniclastics dated below as $34.7 \pm 0.5$ and $33.4 \pm 0.5 \mathrm{Ma}$ above, placing it at or just above, the E-O boundary and is composed of markedly smaller leaves indicative of cooler temperate (Table 1) vegetation. CLAMPderived moist enthalpy from these and sea-level floras in India (Fig. 1 and Table 1) yielded an elevation of $2.9 \pm$ $0.9 \mathrm{~km}$ for the latest Eocene assemblage and $3.9 \pm 0.9 \mathrm{~km}$ for the earliest Oligocene assemblages, matching the modern elevation of $3910 \mathrm{~m}$. The $\sim 1 \mathrm{~km}$ difference between the two assemblages may be genuine or may in part reflect secular cooling across the E-O transition, but such a rapid rise would be consistent with widespread crustal shortening and igneous activity within the Qiangtang terrane at that time (Horton et al. 2002; Kapp et al. 2005).
Tectonism and motion to the SE is ongoing in the Hengduan mountains and Yunnan (Fig. 5), but if nearmodern relief across parts of SE Tibet and NW Yunnan was achieved by the end of the Eocene, when did most of the regional uplift occur? Palaeomagnetic studies of the Gonjo and Ranmugou formations on the eastern Qiangtang terrane (Tong et al. 2017) reveal that both the Lhasa and Qiangtang terranes underwent N-S crustal shortening before 54-43 Ma (early Eocene), while a recent clumped isotope study of radiometrically dated carbonates from the Ranmugou Formation in the Gonjo Basin, $100 \mathrm{~km}$ north of Markam (Fig. 1), showed that the area rose from $\sim 700 \mathrm{~m}$ in the early Eocene (54$50 \mathrm{Ma}$ ) to $\sim 3800 \mathrm{~m}$ by the middle Eocene (44-40 Ma) (Xiong et al. 2020). Unlike earlier studies, Xiong et al. (2020) used an isotope-enabled climate model to verify air parcel trajectories, isotopic lapse rates and assumptions related to the continental effect. This deformation/elevation was followed by $\sim 1300 \pm 410 \mathrm{~km}$ of crustal shortening in the northern Qiangtang terrane after $35.4 \pm 2.4 \mathrm{Ma}$ (Tong et al. 2017) suggesting parts of northern Tibet were being uplifted at this time, perhaps affecting the Qaidam Basin where near current elevations were achieved by $\sim 31 \mathrm{Ma}$ (Song et al. 2020).

\section{The Himalaya}

The Himalaya are the most recent component of the Tibetan region to develop, and although their origin is in the early Eocene, they are essentially a Neogene construct (Ding et al. 2017). An early attempt to quantify the rise of the Himalaya was made nearly 50 years ago after the discovery of Quercus (Quercus sect. Heterobalanus) leaf fossils at a reported modern elevation of $5.6 \mathrm{~km}$ on the 8027-m-high Himalayan peak known as Shishapangma (also known as Gosainthān) (Fig. 1) (Xu et al. 1973). Because the fossils were assigned a Pliocene 
age, it seemed to suggest a very recent Himalayan uplift, but these remains were found only as loose blocks ('float') and their precise origin and exact age remain unknown.

More secure evidence for the growth of the Himalaya was offered by Ding et al. (2017) and Xu et al. (2018), incorporating isotope palaeoaltimetry of Qoumolungma (Mount Everest) (Gébelin et al. 2013) (Fig. 1). They suggest that uplift began in the early Eocene, but it was not until $\sim 26 \mathrm{Ma}$ when the rate of convergence between India and Asia slowed (Meng et al. 2017), that the locus of deformation produced by the India-Eurasia collision moved from Tibet to south of the Gangdese and a rapid acceleration in Himalayan uplift (Ding et al. 2017). This phase of rapid Himalayan development coincided with a slowdown in India's northward motion (Molnar and Stock 2009) (Fig. 4), suggesting greater resistance to further movement was being exerted by the compression of Tibet, which was accompanied by enhanced eastward extrusion. To quantify the rates of Himalayan rise, Ding et al. (2017) and $\mathrm{Xu}$ et al. (2018) used a combination of moist enthalpy derived from radiometrically dated plant fossils and oxygen isotope analysis (Fig. 4).

Moist enthalpy estimates derived from tropical early Eocene $(\sim 56 \mathrm{Ma})$ plants of the Liuqu flora (Fang et al. 2005) (Fig. 1 and Table 1), just south of the YTSZ, show that at that time the land surface had risen to an elevation of $1 \mathrm{~km}$. Locally marine units persisted until $\sim 58.5$ to $\sim 55 \mathrm{Ma}$ (Ding et al. 2005) or even as late as $\sim 50 \mathrm{Ma}$ (Najman et al. 2010). By 24-21 Ma, a CLAMP analysis of the nearby warm temperate Qiabulin flora (Fig. 1 and Table 1) showed a rise to $\sim 2.3 \mathrm{~km}$; an elevation matching that derived from oxygen isotopes $(2.5 \mathrm{~km})$. Analysis of oxygen isotopes from a horizon higher in the Qiabulin section, and radiometrically constrained to be 21-19 Ma, yields an elevation of $\sim 4 \mathrm{~km}$, and by $\sim 15 \mathrm{Ma}$ the Qomolangma (Everest) region had risen to at least $5 \mathrm{~km}$ (Gébelin et al. 2013), reaching the elevation of the Gangdese. It was only after the middle Miocene that the Himalaya rose above the Gangdese and imposed their own influence on atmospheric circulation by virtue of friction from both their height and width, and formed a strong rain shadow effect across Tibet (Ding et al. 2017) (Fig. 14). This led to an inevitable restructuring of air parcel trajectories and atmospheric dynamics across the Tibetan region and beyond.

\section{Concluding remarks-the growth of Tibet, monsoons and biodiversity}

As regards climate and biotic evolution, the most important aspect of the assembly of the Tibetan region has been its complex and dynamic topographic history. By combining isotope and palaeontological palaeoaltimetry with climate modelling, it has been possible to characterise south and central Paleogene Tibet as consisting of two E-W-orientated mountain ranges, the Gangdese and Qiangtang (Tangula) uplands, bounding a wide lowland centred on the BangongNujiang Suture Zone (Fig. 8). Until sometime in the Eocene, this valley drained to the south through the Gangdese (Laskowski et al. 2019), but this ceased as the Himalaya grew and the valley became largely, if not exclusively, internally drained and supported closed lake systems (Ma et al. 2015, 2017). Over time, compression narrowed this valley and marked uplift began at 23.7 Ma (Ma et al. 2017). This compression, together with the internal drainage (Han et al. 2019; Su et al. 2019) and 'bathtub' sediment fill, raised the surface of the valley floor to approach the present central plateau elevation of $\sim 4800 \mathrm{~m}$ in the late Neogene. Some contribution from local lower lithosphere thinning or crustal flow (Han et al. 2019) cannot be ruled out, but this requires further investigation.

This compression in the Eocene, and extending into the early Oligocene, also uplifted parts of northern Tibet, led to the elevation of eastern Tibet and the Hengduan mountains,
Fig. 14 Cartoon showing the rise of the Himalaya and summer rainshadow effect across an elevated $(>4.5 \mathrm{~km})$ Neogene Tibet
S

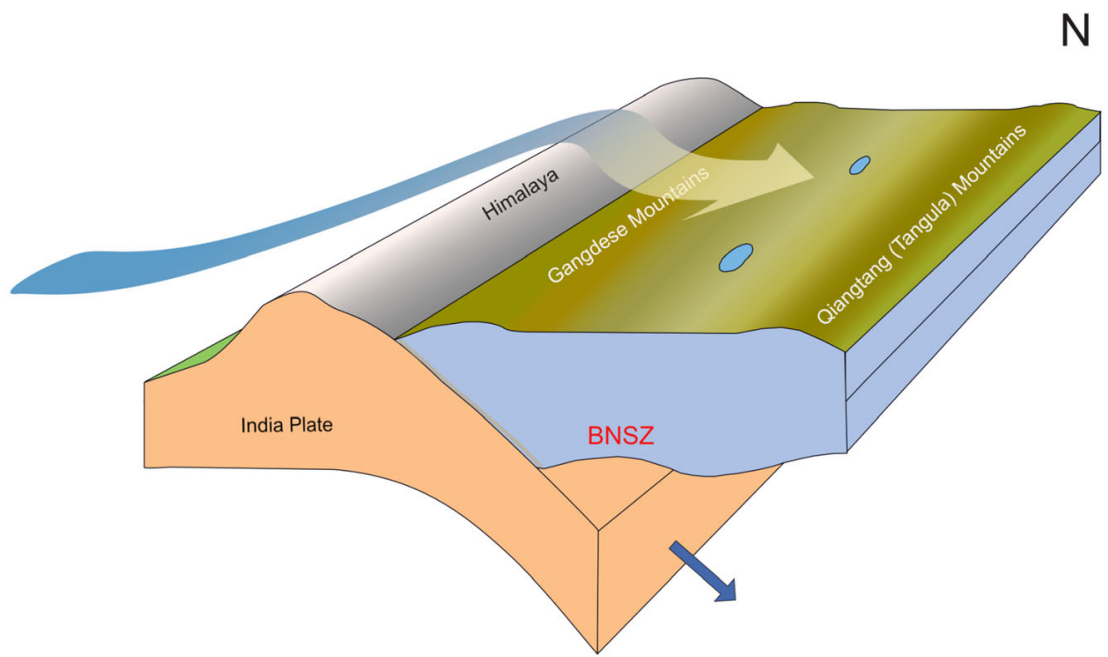


and initiated the rise of the Himalaya. At the end of the Oligocene, deformation across Tibet slowed and switched to building the Himalaya, which showed its fastest rise after 23 Ma coincidental with a slowdown in the rate of India's northward progression. However, only after the midMiocene did the Himalaya substantially exceed the height of the Gangdese to exert a strong drying over the forming plateau, and likely altering the South Asia monsoon system (Boos and Kuang 2010; Molnar et al. 2010) to something resembling its modern state.

There is ample evidence, both qualitative and quantitative, that monsoon systems affecting Asia long pre-date the Miocene (Huber and Goldner 2012; Srivastava et al. 2012; Shukla et al. 2014; Licht et al. 2014; Spicer et al. 2016, 2017) and even the Cenozoic (Armstrong et al. 2016; Farnsworth et al. 2019). If the links between topography and climate are as close as they are argued to be (Boos and Kuang 2010; Molnar et al. 2010), and barring any threshold effects, the incremental development of the Tibetan region should be matched by an incremental evolution of the Asian monsoon systems. It then follows that because those systems display considerable spatial variation in how they are characterised, no single proxy data point can be used reliably to infer the existence, or otherwise, of large-scale monsoon circulation. That aside, it is clear that in the Eocene there was intensification of the monsoon in East Asia (Quan et al. 2011), and southern Asia experienced a monsoonal climate (Shukla et al. 2014), but leaf adaptations suggest that the monsoons across southern Asia had more in common with today's Indonesia-Australia monsoon than the modern South Asia monsoon or East Asia Monsoon (Spicer et al. 2016, 2017). Unlike the Indonesia-Australia monsoon, which is largely a function only of seasonal migrations of the Inter-tropical Convergence Zone, the East Asia and South Asia monsoons appear strongly influenced by topography (Boos and Kuang 2010; Molnar et al. 2010). Both palaeogeography and the topography of the Tibetan region appear to play a greater role in monsoon dynamics than atmospheric carbon dioxide (Farnsworth et al. 2019), so future modelling exercises will need to move away from treating the Tibetan region in a simplistic monotonic fashion, but instead attempt to replicate past orography in as realistic a way as possible. If this does not happen, model-related artefacts will become baked into perceptions of the interplay between orography, climate and biotic systems, and potentially mislead future research directions, just as simplistic thinking has done for the orographic evolution of the Tibetan region.

The interactions between topography, climate and biodiversity in the Tibetan region are complex, but a dynamic high-relief orography offers high levels of niche heterogeneity favouring multiple speciation events (e.g. Spicer 2017, Spicer et al. 2020a; Rahbeck et al. 2019). Numerous molecular phylogenetic analyses suggest intense speciation in the Miocene and many authors have attempted to make links between this diversification and the perceived 'uplift of the Tibetan Plateau' (Renner 2016; Lu et al. 2018). The evidence reviewed here shows that such an uplift of the plateau never happened, instead a high low-relief surface (a plateau) developed as a result of tectonic processes spanning at least 200 million years through a combination of uplift, erosion and sediment-infilling of basins. However, the Miocene is clearly a time by when the Hengduan Mountains, Himalaya and an extensive upland region across Tibet had collectively become established, with associated changes in atmospheric dynamics towards monsoon systems similar to those of the present day. After $15 \mathrm{Ma}$, the Miocene is also a time of global cooling, producing stronger altitudinal thermal gradients and offering new ecological niches for novel plant assemblies such as that of the modern Alpine biome (Ding et al. 2020). It is this development of the modern topography and climate across the Tibetan region that are likely responsible for the Miocene diversification apparent in so many Asian molecular phylogenies (Renner 2016; Lu et al. 2018).

The humid sub-tropical forests of the middle Eocene central valley of Tibet exhibit close floristic links to widely separated parts of the Northern Hemisphere (e.g. Europe, western North America, Africa) (Tang et al. 2019; Del Rio et al. 2020) showing that the valley was not isolated. However, the paucity of taxa in common with India (Liu et al. 2019) shows the strength of the biogeographic barrier posed by the Gangdese mountains compared with the other highlands bounding the valley. From the Late Cretaceous and into the early Paleogene, only one significant river system is known to have cut through the Gangdese Arc uplands (Laskowski et al. 2019). Sedimentologically, the valley system seems internally drained, at least from the late Paleogene onwards (Ma et al. 2015; Han et al. 2019), with sediment buildup eventually contributing to raising the height of the valley floor and creating a plateau late in the Neogene (Su et al. 2019). The bounding mountains seemed to have been high enough to produce a predominance of light stable isotopes in the semi-closed hydrological system within the valley. However, even if we ignore avian propagule dispersal, just a few narrow mountain passes would have been sufficient to afford biotic exchange.

\section{Future work}

Treating Tibet as a monolithic entity rising as a plateau, whether in geodynamic or climate models, confounds our ability to understand the complex interactions between orography, atmospheric dynamics and Asian biodiversity, and ignores major geological properties inherited from Tibet's Mesozoic piecemeal assembly. Tibet evolved by multiple terrane accretion throughout the Mesozoic producing a landscape with complex relief by the time India joined Eurasia early in the Cenozoic. 
Understanding the growth of Tibet, the Himalaya and the Hengduan mountains cannot be undertaken without the use of reliable palaeoaltimetric data. Future work needs to move away from simplistic slab-like treatments of Tibet by integrating into Earth system models more realistic topographic reconstructions derived by combining the various characteristics of different palaeoaltimetric proxies, particularly the rich palaeontological discoveries that are taking place. Through the use of isotopeenabled climate model mediation, new fossil finds and, crucially, radiometric dating, a new synthetic view of Paleogene Tibet is emerging. More detail will undoubtedly unfold as new, precisely dated, fossil finds and stable isotopes are analysed because such data are key components of understanding this landscape evolution, both on the present plateau and across SW China. The interactions between the geometry of Tibet, climate and vegetation are highly complex. To investigate and understand them requires suitably configured models that combine ocean and atmosphere dynamics, realistic palaeogeographies, isotope systems and vegetation/biodiversity feedbacks.

Acknowledgements This work was supported by The Second Tibetan Plateau Scientific Expedition and Research Program (STEP), CAS (Grant No. 2019QZKK0705), National Natural Science Foundation of China (NSFC) (nos. 41922010 (to T.S.) and 41872006 (to F.X.W.)), the Strategic Priority Research Program of CAS (nos. XDA20070301 (to Z.K.Z.), XDA20070203 (to F.X.W.), XDB26000000 (to Z.K.Z. and G.L.S.)); XTBG International Fellowship for Visiting Scientists to R.A.S., the NSFC-NERC (Natural Environment Research Council of the United Kingdom) joint research program (nos. 41661134049 (to T.S.) and NE/P013805/1 (to P.J.V. and A.F.)). We are indebted to two reviewers, Susanne Renner and Gaurav Srivastava, who made invaluable suggestions for improving the manuscript. We thank you both. We are also grateful for the invitation to contribute to this special issue by the guest editors Angela Bruch, Dieter Uhl and Torsten Utescher.

\section{Compliance with ethical standards}

Conflict of interest The authors declare that they have no conflicts of interest.

Open Access This article is licensed under a Creative Commons Attribution 4.0 International License, which permits use, sharing, adaptation, distribution and reproduction in any medium or format, as long as you give appropriate credit to the original author(s) and the source, provide a link to the Creative Commons licence, and indicate if changes were made. The images or other third party material in this article are included in the article's Creative Commons licence, unless indicated otherwise in a credit line to the material. If material is not included in the article's Creative Commons licence and your intended use is not permitted by statutory regulation or exceeds the permitted use, you will need to obtain permission directly from the copyright holder. To view a copy of this licence, visit http://creativecommons.org/licenses/by/4.0/.

\section{References}

Acosta, R. P., \& Huber, M. (2020). Competing topographic mechanisms for the summer Indo-Asian monsoon. Geophysical Research Letters, 47, e2019GL085112.
Acton, G. D. (1999). Apparent polar wander of India since the Cretaceous with implications for regional tectonics and true polar wander. Memoirs of the Geological Society of India, 44, 129-175.

Aitchison, J. C., Davis, A. M., Badengzhu, B., \& Luo, H. (2002). New constraints on the India-Asia collision: the Lower Miocene Gangrinboche conglomerates, Yarlung Tsangpo suture zone, SE Tibet. Journal of Asian Earth Sciences, 21, 251-263.

Allègre, C. J., Courtillot, V., Tapponier, P., Hirn, A., Mattauer, M., Coulon, C., et al. (1984). Structure and evolution of the Himalaya-Tibet orogenic belt. Nature, 307, 17-22. https://doi.org/ 10.1038/307017a0.

Armstrong, H. A., Wagner, T., Herroingshaw, L. G., Farnsworth, A. J., Lunt, D. J., et al. (2016). Hadley circulation and precipitation changes controlling black shale deposition in the Late Jurassic boreal seaway. Paleoceanography, 31, 1041-1053.

Ashton, P. S. (1982). Dipterocarpaceae. In C. G. G. J. van Steenis (Ed.) Flora Malesiana, series 1, Spermatophyta, 9 (pp. 237-552). The Hague: Martinus-Nijhoff Publications.

Ashton, P. S. (2003). Dipterocarpaceae. In K. Kubitzki \& C. Bayer (Eds.) The families and genera of vascular plants $V$ : Flowering plants. Dicotyledons-Malvales, Capparales and Non-betalain Caryophyllales (pp. 182-197). New York: Springer.

B.G.M.R. (1991). The Bureau of Geology and Mineral Resources. (pp. The Regional Geological Map of Mangkang in Tibet $(1: 200,000)$ and Geological Report). Beijing: Geological Publishing House.

Beck, R. A., Burbank, D. W., Sercombe, W. J., Riley, G. W., Barndt, J. K., Berry, J. R., et al. (1995). Stratigraphic evidence for an early collision between northwest India and Asia. Nature, 373(6509), 5558.

Bershaw, J., Penney, S. M., \& Garzione, C. N. (2012). Stable isotopes of modern water across the Himalaya and eastern Tibetan Plateau: implications for estimates of paleoelevation and paleoclimate. Journal of Geophysical Research, 117, D2110. https://doi.org/10. 1029/2011JD016132.

Blisnuik, P., \& Stern, L. (2005). Stable isotope paleoaltimetry: a critical review. American Journal of Science, 305, 1033-1074.

Boos, W. R., \& Kuang, Z. (2010). Dominant control of the South Asian monsoon by orographic insulation versus plateau heating. Nature, 463, 218-222.

Bouilhol, P., Jagoutz, O., Hanchar, J. M., \& Dudas, F. O. (2013). Dating the Indian-Eurasia collision through arc magmatic records. Earth and Planetary Science Letters, 366, 163-175.

Briggs, J. C. (2003). The biogeography and tectonic history of India. Journal of Biogeography, 30(381-388), 397-425.

Burchfiel, B. C., \& Chen, Z. (2012). Tectonics of the southeast Tibetan Plateau and its adjacent foreland. Geological Society of America Memoirs, 210, 1-164.

Burg, J. P., \& Chen, G. M. (1984). Tectonics and structural zonation of southern Tibet, China. Nature, 311, 219-223.

Burg, J. P., Proust, F., Tapponier, P., \& Chen, G. M. (1983). Deformation phases and tectonic evolution of the Lhasa block (southern Tibet, China). Eclogae Geologicae Helvetiae, 76(3), 643-665.

Cai, F., Ding, L., \& Yue, Y. (2011). Provenance analysis of upper Cretaceous strata in the Tethys Himalaya, southern Tibet: implications for timing of India-Asia collision. Earth and Planetary Science Letters, 305(1-2), 195-206.

Cai, C.-K., Huang, D.-Y., Wu, F.-X., Zhao, M., \& Wang, N. (2019). Tertiary water striders (Hemiptera, Gerromorpha, Gerridae) from the central Tibetan Plateau and their palaeobiogeographic implications. Journal of African Earth Sciences, 175, 121-127.

Cao, S. Y., Neubauer, F., Liu, J. 1., Censer, J., \& Leiss, B. (2011). Exhumation of the Diancang Shan metamorphic complex along the Ailao Shan-Red River belt, southwestern Yunnan, China: evidence from Ar-40/Ar-39 thermochronology. Journal of Asian Earth Sciences, 42, 525-550. 
Cao, K., Wang, G.-C., Leloup, P. H., Mahéo, G., Xu, Y., Beek, P. A.van der, et al. (2019). Oligocene-Early Miocene topographic relief generation of southeastern Tibet triggered by thrusting. Tectonics, 38, 374-391.

Cao, M., Sun, J., Liu, W., Hou, J., Tian, Q., \& Sun, Z. (2020). Paleoclimatic fluctuations inferred from leaf wax n-alkane records in Central Tibet in the late Oligocene to early Miocene. Palaeogeogaphy, Palaeoclimatology, Palaeoecology, 539, 109504. https://doi.org/10.1016/j.palaeo.2019.109504.

Cao, Y., Sun, Z., Li, H., Pei, J., Jiang, W., Xu, W., et al. (2017). New Late Cretaceous paleomagnetic data from volcanic rocks and red beds from the Lhasa terrane and its implications for the paleolatitude of the southern margin of Asia prior to the collision with India. Gondwana Research, 41, 337-351.

Chang, C., Chen, N., Coward, M. P., Deng, W., Dewey, J. F., Gansser, A., et al. (1986). Preliminary conclusions of the Royal Society and Academia Sinica 1985 geotraverse of Tibet. Nature, 323, 501-507. https://doi.org/10.1038/323501a0.

Chang, M. M., Miao, D. S., \& Wang, N. (2010). Ascent with modification: fossil fishes witnessed their own group's adaptation to the uplift of the Tibetan Plateau during the late Cenozoic. In M. Y. Long, H. Y. Gu, \& Z. H. Zhou (Eds.) Darwin's heritage today (pp. 60-75). Beijing: Higher Education Press.

Chatterjee, S., \& Scotese, C. R. (1999). The breakup of Gondwana-land and the evolution and biogeography of the Indian plate. Proceedings of the Indiana Academy of Sciences, 65A, 397-425.

Cheng, X. G., Lin, X. B., Wu, L., Chen, H. L., Xiao, A. C., Gong, J. F., et al. (2016). The exhumation history of North Qaidam Thrust Belt constrained by apatite fission track thermochronology: implication for the evolution of the Tibetan Plateau. Acta Geologica Sinica, 90(3), 870-883.

Cheng, J., Garzione, C. N., Jolivet, M., Guo, Z., Zhang, D., Zhang, C., et al. (2019). Initial deformation of the Northern Tibetan Plateau: insights from deposition of the Lulehe Formation in the Qaidam Basin. Tectonics, 38, 741-766. https://doi.org/10.1029/ $2018 \mathrm{TC} 005214$.

Clark, M. K., \& Royden, L. H. (2000). Topographic ooze: building the eastern margin of Tibet by lower crustal flow. Geology, 28, 703706.

Clark, M. K., Schoenbohm, L. M., Royden, L. H., Whipple, K., Burchfiel, B. C., Zhang, B., et al. (2004). Surface uplift, tectonics, and erosion of eastern Tibet from large-scale drainage patterns. Tectonics, 23, TC1006. https://doi.org/10.1029/2002TC001402.

Clark, M. K., Bush, J. W. M., \& Royden, L. H. (2005). Dynamic topography produced by lower crustal flow against rheological strength heterogeneities bordering the Tibetan Plateau. Geophysical Journal International, 162, 575-592.

Clift, P. D., Blusztajn, J., \& Nguyen, A. D. (2006). Large scale drainage capture and surface uplift in eastern Tibet-SW China before $24 \mathrm{Ma}$ inferred from sediments of the Hanoi Basin, Vietnam. Geophysical Research Letters, 33, L19403. https://doi.org/10.1029/ 2006GL027772.

Clift, P. D., Carter, A., Wysocka, A., Long, H. V., Zheng, H., \& Neubeck, N. (2020). A late Eocene-Oligocene through-flowing river between the upper Yangtze and south China sea. Geochemistry, Geophysics, Geosystems. https://doi.org/10.1029/2020GC009046.

Coburn, M. M. (1986). Egg diameter variation in eastern North American minnows (Pisces: Cyprinidae): correlation with vertebral number, habitat and spawning behavior. The Ohio Journal of Science, 86, $110-120$.

Coleman, M., \& Hodges, K. (1995). Evidence for Tibetan plateau uplift before 14 Myr ago from a new minimum age for east-west extension. Nature, 374, 49-52.

Copley, A., Avouac, J. P., \& Royer, J. Y. (2010). India-Asia collision and the Cenozoic slowdown of the Indian plate: implications for the forces driving plate motions. Journal of Geophysical Research Solid Earth, 115, B03410. https://doi.org/10.1029/2009jb006634.

Corlett, R. (2019). The ecology of tropical East Asia (Third ed.). Oxford: Oxford University Press.

Coward, M. P., Kidd, W. S. F., Pan, Y. S., Shackleton, R. M., \& Zhang, H. (1988). The structure of the 1985 Tibet Geotraverse, Lhasa to Golmud. Philosophical Transactions of the Royal Society of London A, 327, 307-336. https://doi.org/10.1098/rsta.1988.0131.

Currie, B. S., Rowley, D., \& Tabor, N. J. (2005). Middle Miocene paleoaltimetry of southern Tibet: implications for the role of mantle thickening and delamination in the Himalayan orogen. Geology, 33, 181-184.

Currie, B. S., Polissar, P. J., Rowley, D., Ingals, M., Li, S., Olack, G., et al. (2016). Multiproxy palaeoaltimetry of the late OligocenePliocene Oiyug Basin, Southern Tibet. American Journal of Science, 316, 401-436.

Dai, J., Zhao, X., Wang, C., Zhu, L., Li, Y., \& Finn, D. (2012). The vast proto-Tibetan Plateau: new constraints from Paleogene Hoh Xil Basin. Gondwana Research, 22(2), 434-446.

Damgaard, J. (2005). Genetic diversity, taxonomy, and phylogeography of the western Palaearctic water strider Aquarius najas (DeGeer) (Heteroptera: Gerridae). Insect Systematics and Evolution, 36, 396-406.

Datta-Roy, A., \& Karanth, K. P. (2009). The Out-of-India hypothesis: what do molecules suggest? Journal of Biosciences, 34, 687-697. https://doi.org/10.1007/s12038-009-0057-8.

DeCelles, P. G., Quade, J., Kapp, P., Fan, M., Dettman, D. L., \& Ding, L. (2007). High and dry in central Tibet during the Late Oligocene. Earth and Planetary Science Letters, 253, 389-401.

Del Rio, C., Wang, T.-X., Liu, J., Liang, S.-L., Spicer, R. A., Wu, F.-X., et al. (2020). Asclepiadospermum gen. nov., the earliest fossil record of Asclepiadoideae (Apocynaceae) from the early Eocene of central Qinghai-Tibetan Plateau, and its biogeographic implications. American Journal of Botany, 107(1), 1-13. https://doi.org/10. 1002/ajb2.1418.

Deng, T., \& Ding, L. (2015). Paleoaltimetry reconstructions of the Tibetan Plateau: progress and contradictions. National Science Review, 2, 417-437. https://doi.org/10.1093/nsr/nwv062.

Deng, L. H., \& Jia, G. D. (2018). High-relief topography of the Nima basin in central Tibetan Plateau during the mid-Cenozoic time. Chemical Geology, 493, 199-209. https://doi.org/10.1016/j. chemgeo.2018.05.041.

Deng, T., Wang, S. Q., Xie, G. P., Li, Q., Hou, S. K., \& Sun, B. Y. (2012). A mammalian fossil from the Dingqing Formation in the Lunpola Basin, northern Tibet, and its relevance to age and paleo-altimetry. China Science Bulletin, 57(2-3), 261-269.

Deng, T., Wang, X.-M., Wu, F.-X., Wang, Y., Wang, S.-Q., \& Hou, S.-K. (2019). Review: Implications of vertebrate fossils for paleoelevations of the Tibetan Plateau. Global and Planetary Change, 174, 58-69.

Dewey, J. F., Shackleton, R. M., Chang, C. F., \& Sun, Y. (1988). The tectonic evolution of the Tibetan Plateau. Philosophical Transactions of the Royal Society of London, A327, 379-413.

Ding, L., Kapp, P., \& Wan, X. (2005). Paleocene-Eocene record of ophiolite obduction and initial India-Asia collision, south central Tibet. Tectonics, 24, TC3001.

Ding, L., Kapp, P., Yue, Y., \& Lai, Q. (2007). Postcollisional calcalkaline lavas and xenoliths from the southern Qiangtang terrane, central Tibet. Earth and Planetary Science Letters, 254, 28-38.

Ding, L., Xu, Q., Yue, Y. H., Wang, H. Q., Cai, F. I., \& Li, S. Q. (2014). The Andean-type Gangdese Mountains: paleoelevation record from the Paleocene-Eocene Linzhou Basin. Earth and Planetary Science Letters, 392, 250-264.

Ding, L., Spicer, R. A., Yang, J., Xu, Q., Cai, F., Li, S., et al. (2017). Quantifying the rise of the Himalaya orogen and implications for the South Asian monsoon. Geology, 45, 215-218. 
Ding, W.-N., Ree, R. H., Spicer, R. A., \& Xing, W.-W. (2020). Ancient orogenic and monsoon-driven assembly of the world's richest temperate alpine flora. Science, 369, 578-581.

Dobretsov, N. L., Buslov, M. M., Delvaux, D., Berzin, N. A., \& Ermikov, V. D. (1996). Meso- and Cenozoic tectonics of the Central Asian mountain belt: effects of lithospheric plate interaction and mantle plumes. International Geology Review, 38, 430-466.

Du, B.-W., Tan, F.-W., \& Chen, M. (2004). Sedimentary features and petroleum geology of the Lunpola Basin, Xizang. Sedimentary Geology and Tethyan Geology, 24, 46-54.

Du, D.-D., Zhang, C. J., Mughal, M. S., Wang, X. Y., Blaise, D., Gao, J. P., et al. (2018). Detrital apatite fission track constraints on Cenozoic tectonic evolution of the northeastern Qinghai-Tibet Plateau, China: evidence from Cenozoic strata in Lulehe section, Northern Qaidam Basin. Journal of Materials Science, 15(3), 532-547.

Dupont-Nivet, G., Krijgsman, W., Langereis, C. G., Abels, H. A., Dai, A., \& Fang, X. M. (2007). Tibetan Plateau aridification linked to global cooling at the Eocene-Oligocene transition. Nature, 445, 635-638.

Dupont-Nivet, G., Hoorn, C., \& Konert, M. (2008). Tibetan uplift prior to the Eocene-Oligocene climate transition: evidence from pollen analysis of the Xining Basin. Geology, 36(12), 987-990.

Eiler, J. M. (2007). "Clumped-isotope" geochemistry - the study of naturally-occurring, multiply-substituted isotopologues. Earth and Planetary Science Letters, 262, 309-327.

Eiler, J. M. (2011). Paleoclimate reconstruction using carbonate clumped isotope thermometry. Quarternary Science Reviews, 30, 33753588.

England, P. C., \& Houseman, G. A. (1988). The mechanics of the Tibetan Plateau. Philosophical Transactions of the Royal Society of London, A326, 301-320.

England, P. C., \& Searle, M. P. (1986). The Cretaceous-Tertiary deformation of the Lhasa block and its implications for crustal thickening in Tibet. Tectonics, 5, 1-14.

Fang, A. M., Yan, Z., Liu, X. H., Pan, Y. S., \& Li, J. L. (2005). The flora of the Liuqu formation in South Tibet and its climate implications. Acta Micropalaeontologica Sinica, 44, 435-445.

Fang, X., Galy, A., Yang, Y., Zhang, W., Ye, C., \& Song, C. (2019). Paleogene global cooling-induced temperature feedback on chemical weathering, as recorded in the northern Tibetan Plateau. Geology, 47, 992-996. https://doi.org/10.1130/G46422.1.

Farnsworth, A., Lunt, D. J., Robinson, S. A., Valdes, P. J., Roberts, W. H. G., Clift, P. D., et al. (2019). Past East Asian monsoon evolution controlled by paleogeography, not $\mathrm{CO}_{2}$. Science Advances, 5 , eaax 1697

Ferguson. (1985). The origin of leaf-assemblages - new light on an old problem. Review of Palaeobotany and Palynology, 46, 117-188.

Fielding, E. J. (1996). Tibet uplift and erosion. Tectonophysics, 260, 5584.

Flohn, H. (1968). Contributions to a meteorology of the Tibetan highlands. Atmospheric Science Papers, Department of Atmospheric Science, Colorado State University, 130.

Forest, C. E., Molnar, P., \& Emanuel, K. A. (1995). Palaeoaltimetry from energy conservation principles. Nature, 374, 347-350.

Forest, C. E., Wolfe, J. A., Molnar, P., \& Emanuel, K. A. (1999). Palaeoaltimetry incorporating atmospheric physics and botanical estimates of palaeoclimate. Geological Society of America Bulletin, $111(4), 497-511$.

Gan, W., Zhang, P., Shen, Z.-K., Niu, Z., Wang, M., Wan, Y., et al. (2007). Present-day crustal motion within the Tibetan Plateau inferred from GPS measurements. Journal of Geophysical Research, 112(10), B08416. https://doi.org/10.1029/2005JB004120

Garzanti, E. (2008). Comment on "When and where did India and Asia collide?" by Jonathan C. Aitchison, Jason R. Ali, and Aileen M. Davis. Journal of Geophysical Research - Solid Earth, 113(B4). https://doi.org/10.1029/2007JB005276.
Garzione, C. N. (2008). Surface uplift of Tibet and Cenozoic global cooling. Geology, 36, 1003-1004.

Garzione, C. N., David, L. D., Quade, J., DeCelles, P. G., \& Butler, R. F. (2000). High times on the Tibetan Plateau: palaeoelevation of the Thakkhola graben, Nepal. Geology, 28(4), 339-342.

Garzione, C. N., Dettman, D. L., \& Horton, B. K. (2004). Carbonate oxygen isotope palaeoaltimetry: evaluating the effect of diagenesis on palaeolevation estimates for the Tibetan plateau. Paleogeography, Paleoclimatology, Paleoecology, 212(1-2), 119-140.

Gébelin, A., Mulch, A., Teyssier, C., Jessup, M. J., Law, R. D., \& Brunel, M. (2013). The Miocene Elevation of Mount Everest. Geology, 41, 799-802.

Gehrels, G., Kapp, P., DeCelles, P. G., Pullen, A., Blakey, R., Weislogel, A., et al. (2011). Detrital zircon geochronology of pre-Tertiary strata in the Tibetan-Himalayan orogen. Tectonics, 30(5), TC5016.

Gourbet, L., Leloup, P. H., Paquette, J.-L., Sorrel, P., Maheo, G., Wang, G.-C., et al. (2017). Reappraisal of the Jianchuan Cenozoic basin stratigraphy and its implications on the SE Tibetan plateau evolution. Tectonophysics, 700-7001, 162-179.

Graham, S. A., Chamberlain, C. P., Yue, Y., Ritts, B. D., Hanson, A. D., Horton, T. W., et al. (2005). Stable isotope records of Cenozoic climate and topography, Tibetan Plateau and Tarim Basin. American Journal of Science, 305, 101-118.

Guan, P., \& Jian, X. (2013). The Cenozoic sedimentary record in Qaidam Basin and its implications for tectonic evolution of the Northern Tibetan Plateau. Acta Sedimentologica Sinica, 31(5), 824-833.

Guillot, S., Mahéo, G., de Sigoyer, J., Hattori, K., \& Pecher, A. (2008). Tethyan and Indian subduction viewed from the Himalayan high- to ultrahigh-pressure metamorphic rocks. Tectonophysics, 451(1), 225-241.

Guillot, S., Goussin, F., Airaghi, L., Replumaz, A., deSigoyer, J., \& Cordier, C. (2019). How and when did the Tibetan Plateau grow? Russian Geology and Geophysics, 60, 957-977.

Guo, S.-X., Spicer, R. A., Widdowson, M., Herman, A. B., \& Domogatskaya, K. V. (2019). The composition of the Middle Miocene (15 Ma) Namling Palaeoflora, South Central Tibet, in the context of other Tibetan and Himalayan floras. Review of Palaeobotany and Palynology, 271, 104088. https://doi.org/10. 1016/j.revpalbo.2019.06.011.

Haider, V. L., Dunkl, I., von Eynatten, H., Ding, L., Frei, D., \& Zhang, L. (2013). Cretaceous to Cenozoic evolution of the northern Lhasa terrane and the Early Paleocene development of peneplains at Nam Co, Tibetan Plateau. Journal of Asian Earth Sciences, 70-71, 79-98. https://doi.org/10.1016/j.jseaes.2013.03.005.

Han, Z., Sinclair, H. D., Li, Y., Wang, C. S., Tao, Z., \& Qiang, et al. (2019). Internal drainage has sustained low-relief Tibetan landscapes since the Early Miocene. Geophysical Research Letters, 46, 8741-8752. https://doi.org/10.1029/2019GL083019.

Harrison, T. M., Copeland, P., Kidd, W. S. F., \& Yin, A. (1992). Raising Tibet. Science, 255, 1663-1670.

He, H.-Y., Sun, J., Li, Q., \& Zhu, R. (2012). New age determination of the Cenozoic Lunpola basin, central Tibet. Geological Magazine, 149(1), 141-145.

He, P. J., Song, C. H., Wang, Y. D., Chen, L. H., Chen, P. C., Wang, Q. Q., et al. (2017). Cenozoic exhumation in the Qilian Shan, northeastern Tibetan Plateau: evidence from detrital fission track thermochronology in the Jiuquan Basin. Journal of Geophysical Research - Solid Earth, 122(8), 6910-6927.

Hetzel, R., Dinkl, I., Haider, V., Strobl, M., von Eynatten, H., Ding, L., et al. (2011). Peneplain formation in southern Tibet predates the India-Asia collision and plateau uplift. Geology, 39, 983-986. https://doi.org/10.1130/G32069.

Hinsbergen, D. J. J. van (2019). Comment on "Comparing Paleomagnetic study means with apparent wander paths: a case study and paleomagnetic test of the Greater India versus Greater Indian Basin 
hypotheses" by David B. Rowley. Tectonics. https://doi.org/10. 1029/2019TC005525.

Hinsbergen, D. J. J. van, Lippert, P. C., Dupont-Nivet, G., McQuarrie, N., Doubrovine, P. V., et al. (2012). Greater India Basin hypothesis and a two-stage Cenozoic collision between India and Asia. Proceedings of the National Academy of Sciences of the United States of America, 109(20), 7659-7664.

Hinsbergen, D. J. J. van, Lippert, P. C., Li, S., Huang, W., Advokaat, E. L., \& Spakman, W. (2019). Reconstructing Greater India: paleogeographic, kinematic, and geodynamic perspectives. Tectonophysics, 760, 69-94.

Hoke, G. D. (2018). Geochronology transforms our view of how Tibet's southeast margin evolved. Geology, 46, 95-96. https://doi.org/10. 1130/focus012018.1.

Hoke, G. D., Liu-Zeng, J., Hren, M. T., Wissink, G. K., \& Garzione, C. N. (2014). Stable isotopes reveal high southeast Tibetan Plateau margin since the Paleogene. Earth and Planetary Science Letters, 394, 270-278.

Horton, B. K., Spurlin, M. S., Zhou, J. Y., \& Wang, J. H. (2002). Paleocene-Eocene syncontractional sedimentation in narrow, lacustrine-dominated basins of east-central Tibet. Geological Society of America Bulletin, 114, 771-786.

Hu, X., Sinclair, H. D., Wang, J., Jiang, H. C., \& Wu, F. (2012). Late Cretaceous-Palaeogene stratigraphic and basin evolution in the Zhepure Mountain of southern Tibet: implications for the timing of India-Asia initial collision. Basin Research, 24, 520-543.

Huang, W., van Hinsbergen, D. J. J., Maffione, M., Orme, D. A., DupontNivet, G., Guilmette, C., et al. (2015). Lower Cretaceous Xigaze ophiolites formed in the Gangdese forearc: evidence from paleomagnetism, sediment provenance, and stratigraphy. Earth and Planetary Science Letters, 415, 142-153. https://doi.org/10.1016/j. epsl.2015.01.032

Huang, Y.-J., Jia, L., Wang, Q., Mosbrugger, V., Utescher, T., Su, T., et al. (2016). Cenozoic plant diversity of Yunnan: a review. Plant Diversity, 38, 271-282.

Huber, B. T., \& Goldner, A. (2012). Eocene monsoons. Journal of Asian Earth Sciences, 44, 3-23.

Huntingdon, K. W., Saylor, J. E., Quade, J., \& Hudson, A. M. (2015). High late Miocene-Pliocene elevation of the Zhada Basin, southwestern Tibetan Plateau, from carbonate clumped isotope thermometry. Geological Society of America Bulletin, 127, 181-199. https:// doi.org/10.1130/B31000.1

Immerzeel, W. W., Lutz, A. F., Andrade, M., Bahl, A., Biemans, H., et al. (2020). Importance and vulnerability of the world's water towers. Nature, 577, 364-369.

Inglis, G. N., Farnsworth, A., Collinson, M. E., Carmichael, M. J., Naafs, B. D. A., Lunt, D. J., et al. (2019). Terrestrial environmental change across the onset of the PETM and the associated impact on biomarker proxies: a cautionary tale. Global and Planetary Change, 181, 102991. https://doi.org/10.1016/j.gloplacha.2019.102991.

Jaeger, J. J., Courtillot, V., \& Tapponnier, P. (1989). Paleontological view of the ages of the Deccan traps, the Cretaceous/Tertiary boundary, and the India-Asia collision. Geology, 17, 316-319.

Ji, J. L., Zhang, K. X., Clift, P. D., Zhuang, G. S., Song, B. W., Ke, X., et al. (2017). High-resolution magnetostratigraphic study of the Paleogene-Neogene strata in the Northern Qaidam Basin: implications for the growth of the Northeastern Tibetan Plateau. Gondwana Research, 46, 141-155.

Jia, L.-B., Su, T., Huang, Y.-J., Wu, F.-X., Deng, T., \& Zhou, Z.-K. (2019). First fossil record of Cedrelospermum (Ulmaceae) from the Qinghai-Tibetan Plateau: implications for morphological evolution and biogeography. Journal of Systematics and Evolution, 57, 94-104.

Jian, X., Guan, P., Zhang, W., Liang, H. H., Feng, F., \& Fu, L. (2018). Late Cretaceous to early Eocene deformation in the northern Tibetan
Plateau: detrital apatite fission track evidence from northern Qaidam basin. Gondwana Research, 60, 94-104.

Jiang, H., Su, T., Wong, W. O., Wu, F., Huang, J., \& Shi, G. (2019). Oligocene Koelreuteria (Sapindaceae) from the Lunpola Basin in central Tibet and its implication for early diversification of the genus. Journal of Asian Earth Sciences, 175, 99-108.

Kapp, P., \& DeCelles, P. G. (2019). Mesozoic-Cenozoic geological evolution of the Himalayan-Tibetan Orogen and working tectonic hypotheses. American Journal of Science, 319, 159-254. https://doi. org/10.2475/03.2019.01

Kapp, P., Yin, A., Harrison, T. M., \& Ding, L. (2005). CretaceousTertiary shortening, basin development, and volcanism in central Tibet. Geological Society of America Bulletin, 117, 865-878. https://doi.org/10.1130/B25595.1.

Kapp, P., DeCelles, P. G., Gehrels, G., Heizler, M., \& Ding, L. (2007a). Geological records of the Lhasa-Qiangtang and Indo-Asian collisions in the Nima basin area, central Tibet. Geological Society of America Bulletin, 119(7-8), 917-933. https://doi.org/10.1130/ B26033.1.

Kapp, P., DeCelles, P. G., Leier, A. L., Fabijanic, J. M., He, S., Pullen, A., et al. (2007b). The Gangdese retroarc thrust belt revealed. GSA Today, 17(7), 4-9. https://doi.org/10.1130/GSAT01707A.1.

Kelley, S., Beaumont, C., \& Butler, J. P. (2019). Inherited terrane properties explain enigmatic post-collisional Himalayan-Tibetan evolution. Geology, 48, 8-14. https://doi.org/10.1130/G46701.1.

Kent-Corson, M. L., Ritts, B. D., Zhuang, G., Bovet, P. M., Graham, S. A., \& Page Chamberlain, C. (2009). Stable isotopic constraints on the tectonic, topographic, and climatic evolution of the northern margin of the Tibetan Plateau. Earth and Planetary Science Letters, 282, 158-166.

Kershaw, A. P., \& Nix, H. A. (1988). Quantitative palaeoclimatic estimates from pollen data using bioclimatic profiles of extant taxa. Journal of Biogeography, 15, 589-602.

Khan, M. A., Spicer, R. A., Bera, S., Ghosh, R., Yang, J., Spicer, T. E. V., et al. (2014). Miocene to Pleistocene floras and climate of the Eastern Himalayan Siwaliks, and new palaeoelevation estimates for the Namling-Oiyug Basin, Tibet. Global and Planetary Change, 113, 1-10.

Kim, S.-T., \& O'Neil, J. R. (1997). Equilibrium and nonequilibrium oxygen isotope effects in synthetic carbonates. Geochemica et Cosmochemica Acta, 61, 3461-3475.

Klaus, S., Morely, R. J., Plath, M., Zhang, Y.-P., \& Li, J.-T. (2016). Biotic interchange between the Indian subcontinent and mainland Asia through time. Nature Communications, 7, 12132. https://doi. org/10.1038/ncomms12132.

Laskowski, A. K., O'rme, D. A., Cai, F., \& Ding, L. (2019). The Ancestral Lhasa River: a Late Cretaceous trans-arc river that drained the proto-Tibetan Plateau. Geology, 47, 1029-1033.

Law, R. D., \& Allen, M. B. (2019). Diachronous Tibetan Plateau landscape evolution derived from lava field geomorphology. Geology, 48, 263-267. https://doi.org/10.1130/G47196.1.

Leech, M. L., Singh, S., Jain, A., Klemperer, S. L., \& Manickavasagam, R. (2005). The onset of India-Asia continental collision: early, steep subduction required by the timing of UHP metamorphism in the western Himalaya. Earth and Planetary Science Letters, 234(1), 83-97.

Leier, A. L., DeCelles, P. G., Kapp, P., \& Ding, L. (2007). The Takena Formation of the Lhasa terrane, southern Tibet. Geological Society of America Bulletin, 119, 31-48. https://doi.org/10.1130/B25974.1.

Leier, A. L., Quade, J., \& Kapp, P. (2009). Stable isotopic results from paleosol carbonate in South Asia: paleoenvironmental reconstructions and selective alteration. Earth and Planetary Science Letters, 279, 242-254. https://doi.org/10.1016/j.eps1.2008.12.044.

Leloup, P. H., Lacassin, R., Tapponier, P., Schärer, U., Zhong, D. L., Liu, X. H., et al. (1995). The Ailao Shan-Red River shear zone (Yunnan, 
China), Tertiary transform boundary of Indochina. Tectonophysics, 251,3-84.

Li, J. T., Li, Y., Klaus, S., Rao, D.-Q., Hillis, D. M., \& Zhang, Y.-P. (2013). Diversification of rhacophorid frogs provides evidence for accelerated faunal exchange between India and Eurasia during the Oligocene. Proceedings of the National Academy of Sciences of the United States of America, 110(9), 3441-3446.

Li, S., Currie, B. S., Rowley, D. B., \& Ingalls, M. (2015). Cenozoic paleoaltimetry of the SE margin of the Tibetan Plateau: constraints on the tectonic evolution of the region. Earth and Planetary Science Letters, 432, 415-424.

Li, L., Garzione, C. N., Pullen, A., \& Chang, H. (2016). Early-middle Miocene topographic growth of the northern Tibetan Plateau: stable isotope and sedimentation evidence from the southwestern Qaidam basin. Palaeogeogaphy, Palaeoclimatology, Palaeoecology, 461, 201-213. https://doi.org/10.1016/j.palaeo.2016.08.025.

Li, J. F., Zhang, Z. C., Zhao, Y., Pei, J. L., Tang, W. H., \& Li, K. (2017a). Detrital apatite fission track analyses of the Subei basin: implications for basin-range structure of the northern Tibetan Plateau. International Geology Review, 59(2), 204-218.

Li, S.-H., Advokaat, E. L., van Hinsbergen, D. J. J., Koymans, M., Deng, C.-L., \& Zhu, R. (2017b). Paleomagnetic constraints on the Mesozoic-Cenozoic paleolatitudinal and rotational history of Indochina and South China: review and updated kinematic reconstruction. Earth Science Reviews, 171, 58-77. https://doi.org/10. 1016/j.earscirev.2017.05.007.

Li, S.-H., Su, T., Spicer, R. A., Xu, C., Sherlock, S., Halton, A., Hoke, G., Tian, Y., Zhou, Z.-K., Deng, C.-L., \& Zhu, R.-X. (2020). Oligocene deformation of the Chuandian terrane in the SE margin of the Tibetan Plateau related to the extrusion of Indochina. Tectonics, 39, e2019TC005974. https://doi.org/10.1029/2019TC005974.

Licht, A., van Cappelle, M., Abels, H. A., Ladant, J. B., TrabuchoAlexandre, J., FranceLanord, C., et al. (2014). Asian monsoons in a late Eocene greenhouse world. Nature, 513, 501-506.

Liebke, U., Appel, E., Ding, L., Neumann, U., Antolin, B., \& Xu, Q. (2010). Position of the Lhasa terrane prior to India-Asia collision derived from palaeomagnetic inclinations of $53 \mathrm{Ma}$ old dykes of the Linzhou Basin: constraints on the age of collision and postcollisional shortening within the Tibetan Plateau. Geophysical Journal International, 182(3), 1199-1215.

Lin, J., Dai, J., Zhuang, G., Jia, G., Zhang, L., Ning, Z., et al. (2020). Late Eocene-Oligocene high relief paleotopography in the north-central Tibetan Plateau: insights from detrital zircon U-Pb geochronology and leaf wax hydrogen isotope studies. Tectonics, 39, e2019TC005815. https://doi.org/10.1029/2019TC005815.

Linnemann, U., Su, T., Kunzmann, L., Spicer, R. A., Ding, W.-N., Spicer, T. E. V., et al. (2018). New U-Pb dates show a Paleogene origin for the modern Asian biodiversity hot spots. Geology, 46, $3-$ 6.

Liu, X.-H., Xu, Q., \& Ding, L. (2016). Differential surface uplift: Cenozoic palaeoelevation history of the Tibetan Plateau. Science China Earth Sciences, 59, 2105-2120.

Liu, J., Su, T., Spicer, R. A., Tang, H., Deng, W.-Y.-D., Wu, F.-X., et al. (2019). Biotic interchange through lowlands of Tibetan Plateau suture zones during Paleogene. Palaeogeogaphy, Palaeoclimatology, Palaeoecology, 524, 33-40.

Liu-Zheng, J., Zhang, J., McPhillips, D., Reiners, P. W., Wang, W., Pik, R., et al. (2018). Multiple episodes of fast exhumation since Cretaceous in southeast Tibet, revealed by low-temperature thermochronology. Earth and Planetary Science Letters, 490, 6276.

Low, S. L., Su, T., Spicer, T. E. V., Wu, F.-X., Deng, T., Xing, Y.-W., et al. (2019). Oligocene Limnobiophyllum (Araceae) from the central Tibetan Plateau and its evolutionary and palaeoenvironmental implications. Journal of Systematic Palaeontology, 1-17. https:// doi.org/10.1080/14772019.2019.1611673.
Lu, L.-M., Mao, L. F., Yang, T.-N., Ye, J.-F., Liu, B., Li, H.-L., et al. (2018). Evolutionary history of the angiosperm flora of China. Nature, 554, 234-238.

Luo, P., Peng, P. A., Gleixner, G., Zheng, Z., O'ang, Z., \& Ding, Z. (2011). Empirical relationship between leaf wax $n$-alkane $\delta D$ and altitude in the Wuyi, Shennongjia and Tianshan Mountains, China: implications for paleoaltimetry. Earth and Planetary Science Letters, 301, 285-296. https://doi.org/10.1016/j.epsl.2010.11.012.

Ma, P., Wang, L., Wang, C., Wu, X. C., \& Wei, Y. (2015). Organicmatter accumulation of the lacustrine Lunpola oil shale, central Tibetan Plateau: controlled by the paleoclimate, provenance, and drainage system. International Journal of Coal Geology, 147-148, $58-70$.

Ma, P., Wang, C., Meng, J., Ma, C., Zhao, X., Li, Y., et al. (2017). Late Oligocene-early Miocene evolution of the Lunpola Basin, central Tibetan Plateau, evidences from successive lacustrine records. Gondwana Research, 48, 224-236.

Meng, J., Wang, C., Zhao, X., Coe, R. S., Li, Y., \& Finn, D. (2012). India-Asia collision was at $24^{\circ} \mathrm{N}$ and $50 \mathrm{Ma}$ : palaeomagnetic proof from southernmost Asia. Scientific Reports, 2, 925.

Meng, J., Coe, R. S., Wang, C.-S., Gilder, S., Zhao, X., Liu, H., et al. (2017). Reduced convergence within the Tibetan Plateau by $26 \mathrm{Ma}$ ? Geophysical Research Letters, 44. https://doi.org/10.1002/ 2017GL074219.

Metcalfe, I. (2006). Palaeozoic and Mesozoic tectonic evolution and palaeogeography of East Asian crustal fragments: the Korean Peninsula in context. Gondwana Research, 9(1-2), 24-26.

Meyer, H. W. (1992). Lapse rates and other variables applied to estimating paleoaltitudes from fossil floras. Palaeogeography, Palaeoclimatology, Palaeoecology, 99, 71-99.

Meyer, H. W. (2007). A review of paleotemperature-lapse rate methods for estimating paleoelevation from fossil floras. Reviews in Mineralogy and Geochemistry, 66, 155-171.

Molnar, P. (1989). The geological evolution of the Tibetan Plateau. Scientific American, 77, 350-360.

Molnar, P., \& England, P. (1990). Late Cenozoic uplift of mountain ranges and global climate change: chicken or egg? Nature, 346(6279), 29-34.

Molnar, P., \& Stock, J. M. (2009). Slowing of India's convergence with Eurasia since $20 \mathrm{Ma}$ and its implications for Tibetan mantle dynamics. Tectonics, 28, TC3001.

Molnar, P., \& Tapponier, P. (1975). Cenozoic tectonics of Asia: effects of a continental collision. Science, 189(4201), 419-426. https://doi. org/10.1126/science.189.4201.419.

Molnar, P., England, P., \& Martinod, J. (1993). Uplift of the Tibetan Plateau, and the Indian Monsoon. Reviews of Geophysics, 31, 357-396.

Molnar, P., Boos, W. R., \& Battisti, D. S. (2010). Orographic controls on climate and paleoclimate of Asia: thermal and mechanical roles for the Tibetan Plateau. Annual Review of Earth and Planetary Sciences, 38, 77-102.

Morley, R. J. (2000). Origin and evolution of tropical rain forests. Chichester: Wiley.

Mosbrugger, V., \& Utescher, T. (1997). The coexistence approach-a method for quantitative reconstructions of Tertiary terrestrial palaeoclimate data using plant fossils. Paleogeography, Paleoclimatology, Paleoecology, 134, 61-86.

Mulch, A. (2016). Stable isotope paleoaltimetry and the evolution of landscapes and life. Earth and Planetary Science Letters, 433, 180-191. https://doi.org/10.1016/j.epsl.2015.10.034.

Myers, N., Mittermeir, C. G., da Fonseca, G. A. B., \& Kent, J. (2000). Biodiversity hotspots for conservation priorities. Nature, 403, 218 222.

Naafs, B. D. A., Inglis, G. N., Blewett, J., McClymont, E. L., Lauretano, V., Xie, S., et al. (2019). The potential of biomarker proxies to trace 
climate, vegetation, and biogeochemical processes in peat: a review. Global and Planetary Change, 179, 57-79.

Najman, Y., Appel, E., Boudagher-Fadel, M. K., Bown, P., Carter, A., Garzanti, E., et al. (2010). Timing of India-Asia collision: geological, biostratigraphic, and palaeomagnetic constraints. Journal of Geophysical Research - Solid Earth, 115(B12), B12416. https:// doi.org/10.1029/2010JB007673.

Ni, X. J., Li, Q., Zhang, C., Samiullah, K., Zhang, L., Yang, Y., et al. (2020). Paleogene mammalian fauna exchanges and the paleogeographic pattern in Asia. Science China Earth Sciences, 63, 202-211. https://doi.org/10.1007/s11430-019-9479-1.

Nie, J., Ruetenik, G., Gallagher, K., Hoke, G. D., Garzione, C. N., Wang, W., et al. (2018). Rapid incision of the Mekong River in the middle Miocene linked to monsoonal precipitation. Nature Geoscience, 11(12), 944-949.

Orme, D. A., \& Laskowski, A. K. (2016). Basin analysis of the AlbianSantonian Xigaze forearc, Lazi region, south-central Tibet. Journal of Sedimentary Research, 86, 894-913. https://doi.org/10.2110/jsr. 2016.59 .

Ouimet, W., Whipple, K., Royden, L. H., Reiners, P. W., Hodges, K., \& Pringle, M. (2010). Regional incision of the eastern margin of the Tibetan Plateau. Lithosphere, 2(1), 50-63.

Poage, M. A., \& Chamberlain, C. P. (2001). Empirical relationships between elevation and the stable isotope composition of precipitation and surface waters: considerations for studies of paleoelevation change. American Journal of Science, 301, 1-15.

Polissar, P., Freeman, K., Rowley, D., McInerney, F., \& Currie, B. S. (2009). Paleoaltimetry of the Tibetan plateau from D/H ratios of lipid biomarkers. Earth and Planetary Science Letters, 287, 64-76.

Poulsen, C. J., \& Jeffery, M. L. (2011). Climate change imprinting in stable isotopic compositions of high elevation meteoric water cloaks past surface elevation of major orogens. Geology, 39, 595-598.

Povey, D. A. R., Spicer, R. A., \& England, P. C. (1994). Palaeobotanical investigation of early Tertiary palaeoelevations in northeastern Nevada: initial results. Review of Palaeobotany and Palynology, $81,1-10$

Prasad, G. V. R., \& Sahni, A. (1999). Were there size constraints on biotic exchanges during the northward drift of the Indian plate? In A. Sahni \& R. S. Loyal (Eds.) Gondwana assemblage: new issues and perspective: Proceedings of the National Science Academy A. 3 (pp. 377-379).

Qi, B. S., Hu, D. G., Yang, X. X., Zhang, Y. L., Tan, C. X., Zhang, P., et al. (2016). Apatite fission track evidence for the CretaceousCenozoic cooling history of the Qilian Shan (NW China) and for stepwise northeastward growth of the northeastern Tibetan Plateau since early Eocene. Journal of Asian Earth Science, 124, 28-41.

Qiu, J. (2008). The Third Pole. Nature, 454, 393-396.

Quade, J., Garzione, C. N., \& Eiler, J. M. (2007). Paleoelevation reconstruction using pedogenic carbonates, paleoaltimetry: geochemical and thermodynamic approaches. Reviews in Mineralogy and Geochemistry, 66, 53-87. https://doi.org/10.2138/rmg.2007.66.3.

Quan, C., Liu, Y. S., \& Utescher, T. (2011). Paleogene evolution of precipitation in Northeastern China supporting the Middle Eocene intensification of the East Asian monsoon. Palaios, 26, 743-753.

Rahbeck, C., Borregaard, M. K., Antonelli, A., Colwell, R. K., Holt, B. G., et al. (2019). Building mountain biodiversity: geological and evolutionary processes. Science, 365, 1114-1119.

Ratschbacher, L., Frisch, W., Chen, C. W., \& Pan, G. (1992). Deformation and motion along the southern margin of the Lhasa Block (Tibet) prior to and during the India-Asia collision. Journal of Geodynamics, 16(1-2), 21-24. https://doi.org/10.1016/02643707(92)90017-M.

Reichgelt, T., West, C. K., \& Greenwood, D. R. (2018). The relation between global palm distribution and climate. Scientific Reports, 8, 4721-4731. https://doi.org/10.1038/s41598-018-23147-2.
Renner, S. S. (2016). Available data point to a 4-km-high Tibetan Plateau by $40 \mathrm{Ma}$, but 100 molecular-clock papers have linked supposed recent uplift to young node ages. Journal of Biogeography, 43, $1479-1487$.

Roger, F., Arnaud, N., Gilder, S., Tapponier, P., Jolivet, M., Brunel, M., et al. (2003). Geochronological and geochemical constraints on Mesozoic suturing in east central Tibet. Tectonics, 22, 1037. https://doi.org/10.1029/2002TC001466.

Rowley, D. (1996). Age of initiation of collision between India and Asia: a review of stratigraphic data. Earth and Planetary Science Letters, $145(1-4), 1-13$.

Rowley, D. B. (2019a). Comparing Paleomagnetic study means with apparent wander paths: a case study and paleomagnetic test of the Greater India versus Greater Indian Basin hypotheses. Tectonics, 38, 722-740. https://doi.org/10.1029/2017TC004802.

Rowley, D. B. (2019b). Reply to comment on 'Comparing Paleomagnetic study means with apparent wander paths: a case study and paleomagnetic test of the Greater India versus Greater Indian Basin hypotheses'. Tectonics. https://doi.org/10.1029/2019TC005740.

Rowley, D., \& Currie, B. S. (2006). Palaeo-altimetry of the late Eocene to Miocene Lunpola basin, central Tibet. Nature, 439, 677-681. https://doi.org/10.1038/nature04506.

Rowley, D. B., \& Garzione, C. N. (2007). Stable isotope-based paleoaltimetry. Annual Review of Earth and Planetary Sciences, 35, 463-508.

Rowley, D., Pierrehumbert, R. T., \& Currie, B. S. (2001). A new approach to stable isotope-based paleoaltimetry; implications for paleoaltimetry and paleohypsometry of the High Himalaya since the late Miocene. Earth and Planetary Science Letters, 188, 253 268.

Royden, L. H., Burchfiel, B. C., King, R. W., Wang, E., Chen, Z. I., Shen, F., et al. (1997). Surface deformation and lower crustal flow in eastern Tibet. Science, 276, 788-790.

Sahni, A., \& Bajpai, S. (1991). Eurasiatic elements in the Upper Cretaceous nonmarine biotas of peninsular India. Cretaceous Research, 12, 177-183.

Sahni, A., \& Prasad, G. V. R. (2008). Geodynamic evolution of the Indian Plate: consequences for dispersal distribution of biota. Golden Jubilee Memorial Geological Society of India, 66, 203-225.

Samant, B., Mohabey, D. M., \& Paudayal, K. N. (2013). Aquilapollenites and other triprojectate pollen from the Late Cretaceous to Early Paleocene Deccan intertrappean deposits of India. Palynology, 37(2), 298-315. https://doi.org/10.1080/01916122.2013.787125.

Saylor, J. E., Quade, J., Dettman, D. L., DeCelles, P. G., Kapp, P. A., \& Ding, L. (2009). The late Miocene through present paleoelevation history of southwestern Tibet. American Journal of Science, 309(1), $1-42$.

Searle, M. P. (2006). Role of the Red River Shear zone, Yunnan and Vietnam, in the continental extrusion of SE Asia. Journal of the Geological Society, London, 163, 1025-1036.

Şengör, A. C. (1984). The Cimmeride orogenic system and the tectonics of Eurasia. Special Paper of the Geological Society of America, 195, $1-74$.

Shukla, A., Mehrotra, N. C., Spicer, R. A., Spicer, T. E. V., \& Kumar, M. (2014). Cool equatorial terrestrial temperatures and the South Asian monsoon in the Early Eocene: evidence from the Gurha Mine, Rajasthan, India. Palaeogeography Palaeoclimatology Palaeoecology, 412, 187-198.

Sigoyer, J. de., Chavagnac, V., Blichert-Toft, J., Villa, I. M., Luais, B., Guillot, S., et al. (2000). Dating the Indian continental subduction and collisional thickening in the northwest Himalaya: multichronology of the Tso Morari eclogites. Geology, 28(6), 487-490.

Skelton, P. H. (2001). A complete guide to the freshwater fishes of southern Africa. Cape Town, Struik.

Song, X.-Y., Spicer, R. A., Yang, J., Yao, Y.-F., \& Li, C.-S. (2010), Pollen evidence for an Eocene to Miocene elevation of central 
southern Tibet predating the rise of the High Himalaya. Palaeogeography, Palaeoclimatology, Palaeoecology, 297, 159168.

Song, B. W., Zhang, K., Hou, Y., Ji, J. L., Wang, J., Yang, Y., et al. (2019). New insights into the provenance of Cenozoic strata in the Qaidam Basin, northern Tibet: constraints from combined U-Pb dating of detrital zircons in recent and ancient fluvial sediments. Palaeogeogaphy, Palaeoclimatology, Palaeoecology, 533, 109254. https://doi.org/10.1016/j.palaeo.2019.109254.

Song, B. W., Spicer, R. A., Zhang, K., Ji, J. L., Farnsworth, A., Hughes, A. C., et al. (2020). Qaidam Basin leaf fossils show northeastern Tibet was high, wet and cool in the early Oligocene. Earth and Planetary Science Letters, 537, 116175. https://doi.org/10.1016/j. eps1.2020.116175.

Spicer, R. A. (1981). The sorting and deposition of allochthonous plant material in a modern environment at Silwood Lake, Silwood Park, Berkshire. United States Geological Survey Professional Paper, 1143, 1-77.

Spicer, R. A. (2017). Tibet, the Himalaya, Asian monsoons and biodiversity - in what ways are they related? Plant Diversity, 39, 233-244. https://doi.org/10.1016/j.pld.2017.09.001.

Spicer, R. A. (2018). Phytopaleoaltimetry: using plant fossils to measure past land surface elevation. In C. Hoorn, A. Perrigo, \& A. Antonelli (Eds.) Mountains, climate and biodiversity (pp. 95-109). Wiley Blackwell.

Spicer, R. A., \& Wolfe, J. A. (1987). Plant taphonomy of late Holocene deposits in Trinity (Clair Engle) Lake, northern California. Paleobiology, 13, 227-245.

Spicer, R. A., \& Yang, J. (2010). Quantification of uncertainties in fossil leaf paleoaltimetry - does leaf size matter? Tectonics, 29, TC6001.

Spicer, R. A., Harris, N. B. W., Widdowson, M., Herman, A. B., Guo, S., Valdes, P. J., et al. (2003). Constant elevation of Southern Tibet over the past 15 million years. Nature, 412, 622-624.

Spicer, R. A., Herman, A. B., \& Kennedy, E. M. (2005). The sensitivity of CLAMP to taphonomic loss of foliar physiognomic characters. Palaios, 20, 429-438.

Spicer, R. A., Valdes, P. J., Spicer, T. E. V., Craggs, H. J., Srivastava, G., Mehrotra, R. C., et al. (2009). New developments in CLAMP: calibration using global gridded meteorological data. Palaeogeography, Palaeoclimatology, Palaeoecology, 283, 91-98.

Spicer, R. A., Yang, J., Herman, A. B., Kodrul, T., Maslova, N., Spicer, T. E. V., et al. (2016). Asian Eocene monsoons as revealed by leaf architectural signatures. Earth and Planetary Science Letters, 449, $61-68$.

Spicer, R. A., Yang, J., Herman, A. B., Kodrul, T., Aleksandrova, G., Maslova, N., et al. (2017). Paleogene monsoons across India and South China: drivers of biotic change. Gondwana Research, 49, 350-363.

Spicer, R. A., Farnsworth, A., \& Su, T. (2020a). Cenozoic topography, monsoons and biodiversity conservation within the Tibetan region: an evolving story. Plant Diversity. https://doi.org/10.1016/j.pld. 2020.06.011.

Spicer, R. A., Su, T., Valdes, P. J., Farnsworth, A., Wu, F.-X., Shi, G., Spicer, T. E. V., et al. (2020b). Why the 'Uplift of the Tibetan Plateau' is a myth. National Science Review, nwaa091. https://doi. org/10.1093/nsr/nwaa091.

Spurlin, M. S., Yin, A., Horton, B. K., Zhou, J., \& Wang, J. (2005). Structural evolution of the Yushu-Nangqian region and its relationship to syncollisional igneous activity, east-central Tibet. Geological Society of America Bulletin, 117, 1293-1317.

Srivastava, G., Spicer, R. A., Spicer, T. E. V., Yang, J., Kumar, M., Mehrotra, R. C., et al. (2012). Megaflora and palaeoclimate of a Late Oligocene tropical delta, Makum Coalfield, Assam: evidence for the early development of the South Asia Monsoon. Palaeogeography, Palaeoclimatology, Palaeoecology, 342-343, 130-142. https://doi. org/10.1016/j.palaeo.2012.05.002.
St-Onge, M. R., Rayner, N., \& Searle, M. P. (2010). Zircon age determinations for the Ladakh batholith at Chumathang (Northwest India): implications for the age of the India-Asia collision in the Ladakh Himalaya. Tectonophysics, 495(3), 171-183.

Strobl, M., Hetzel, R., Niedermann, S., Ding, L., \& Zhang, L. (2012). Landscape evolution of a bedrock peneplain on the southern Tibetan Plateau revealed by in situ-produced cosmogenic $10 \mathrm{Be}$ and $12 \mathrm{Ne}$. Geomorphology, 153, 192-204.

Sturm, C., Zhang, Q., \& Noone, D. (2010). An introduction to stable water isotopes in climate models: benefits of forward proxy modeling for paleoclimatology. Climate of the Past, 6, 115-129.

Su, T., Wilf, P., Xu, H., \& Zhou, Z.-K. (2014). Miocene leaves of Elaeagnus (Elaeagnaceae) from the Qinghai-Tibet Plateau, its modern center of diversity and endemism. American Journal of Botany, 101(8), 1350-1361.

Su, T., Spicer, R. A., Li, S.-H., Xu, H., Huang, J., Sherlock, S., et al. (2018). Climate and biotic changes at the Eocene-Oligocene transition in Southeast Tibet. National Science Review, 6, 495-504. https://doi.org/10.1093/nsr/nwy062.

Su, T., Farnsworth, A., Spicer, R. A., Huang, J., Wu, F.-X., Liu, J., et al. (2019). No high Tibetan Plateau until the Neogene. Science Advances, 5, eaav2189.

Sun, J., Xu, Q., Liu, W., Zhang, Z., Xue, L., \& Zhao, P. (2014a). Palynological evidence for the latest Oligocene-early Miocene paleoelevation estimate in the Lunpola Basin, central Tibet. Palaeogeogaphy, Palaeoclimatology, Palaeoecology, 399, 21-30.

Sun, T., Wang, C. S., Duan, Y., Li, Y. L., \& Hu, B. (2014b). The organic geochemistry of the Eocene-Oligocene black shales from the Lunpola Basin, central Tibet. Journal of Asian Earth Sciences, 79, 468-476.

Sun, G., Hu, X., Sinclair, H. D., BouDagher-Fadel, M. K., \& Wang, J. (2015a). Late Cretaceous evolution of the Coqen Basin (Lhasa terrane) and implications for early topographic growth on the Tibetan Plateau. Geological Society of America Bulletin, 127, 1001-1020. https://doi.org/10.1130/B31137.1.

Sun, J. M., Gong, Z. J., Tian, Z. H., Jia, Y. Y., \& Windley, B. (2015b). Late Miocene stepwise aridification in the Asian interior and the interplay between tectonics and climate. Palaeogeography Palaeoclimatology Palaeoecology, 421, 48-59.

Tang, H., Liu, J., Wu, F.-X., Magner, T. E. V., Spicer, R. A., Deng, W.Y.-D., et al. (2019). An extinct genus Lagokarpos reveals a biogeographic connection of the Tibet with other regions in the Northern Hemisphere during the Paleogene. Journal of Systematics and Evolution, 57(6), 670-677. https://doi.org/10.1111/jse.12505.

Tang, H., Li, S.-F., Su, T., Spicer, R. A., Zhang, S.-T., Li, S.-H., Liu, J., Lauretanao, V., Witkowski, C., Spicer, T. E. V., Deng, W.-Y.-D., Wu, M.-X., Ding, W. N., \& Zhou, Z.-K. (2020). Early Oligocene vegetation and climate of southwestern China inferred from palynology. Palaeogeography, Palaeoclimatology, Palaeoecology. https://doi.org/10.1016/j.palaeo.2020.109988.

Tao, J. R., \& Du, N. Q. (1987). Miocene flora from Markam County and fossil record of Betulaceae. Acta Botanica Sinica, 29, 649-655.

Tapponnier, P., Lacassin, R., Leloup, P. H., Scharer, U., Zhong, D. L., Wu, H. W., et al. (1990). The Ailao Shan Red River metamorphic belt - Tertiary left-lateral shear between Indochina and South China. Nature, 343, 431-437.

Tapponnier, P., Xu, Z. Q., Roger, F., Meyer, B., Arnaud, N., Wittlinger, G., et al. (2001). Oblique stepwise rise and growth of the Tibet Plateau. Science, 294, 1671-1677.

Tong, Y., Yang, Z., Mao, C., Pei, J., Pu, Z., \& Xu, Y. (2017). Paleomagnetism of Eocene red-beds in the eastern part of the Qiangtang Terrane and its implications for uplift and southward crustal extrusion in the southeastern edge of the Tibetan Plateau. Earth and Planetary Science Letters, 475, 1-14.

Utescher, T., Bruch, A. A., Erdei, B., Francois, L., Ivanaov, D., Jacques, F. M. B., et al. (2014). The Coexistence Approach-theoretical 
background and practical considerations of using plant fossils for climate quantification. Palaeogeography, Palaeoclimatology, Palaeoecology, 410, 58-73.

Viviroli, D., Dürr, H. H., Messerli, B., Meybeck, M., \& Weingartner, R. (2007). Mountains of the world, water towers for humanity: typology, mapping, and global significance. Water Resources Research, 43, 1-13.

Wang, N., \& Wu, F.-X. (2015). New Oligocene cyprinid in the central Tibetan Plateau documents the pre-uplift tropical lowlands. Ichthyological Research, 62, 274-285.

Wang, K. F., Yang, J. W., Li, Z., \& Li, Z. R. (1975). On the Tertiary sporo-pollen assemblages from Lunpola Basin of Xizang, China and their palaeogeographic significance. Scientia Geologica Sinica, 4, 366-374.

Wang, Y., Deng, T., \& Biasatti, D. (2006). Ancient diets indicate significant uplift of southern Tibet after ca. 7 Ma. Geology, 34, 309-312.

Wang, C., Zhao, X., Liu, Z., Lippert, P. C., Graham, S. A., Coe, R. S., et al. (2008). Constraints on the early uplift history of the Tibetan Plateau. Proceedings of the National Academy of Sciences of the United States of America, 105, 4987-4992. https://doi.org/10. 1073/pnas.0703595105.

Wang, J., Hu, X., Jansa, L., \& Huang, Z. (2011). Provenance of the Upper Cretaceous-Eocene deep-water sandstones in Sangdanlin, southern Tibet: constraints on the timing of initial India-Asia collision. Journal of Geology, 119, 293-309.

Wang, E., Kirby, E., Furlong, K. P., van Soest, M., Xu, G., Shi, X. G., et al. (2012). Two-phase growth of high topography in eastern Tibet during the Cenozoic. Nature Geoscience, 5(9), 640-645.

Wang, C. S., Dai, J., Zhao, X., Li, Y., Graham, S. A., He, D., et al. (2014). Outward-growth of the Tibetan Plateau during the Cenozoic: a review. Tectonics, 621, 1-43.

Wang, Y. D., Zheng, J. J., Zheng, Y. W., Liu, W. W., \& G.Q., S. (2015). Paleocene-Early Eocene uplift of the Altyn Tagh Mountain: evidence from detrital zircon fission track analysis and seismic sections in the northwestern Qaidam basin. Journal of Geophysical Research - Solid Earth, 120, 8534-8550.

Wang, Y., Zhang, B., Schoenbohm, L. M., Zhang, J.-J., Zhou, R., Hou, J.-J., et al. (2016). Late Cenozoic tectonic evolution of the Ailao Shan-Red River fault (SE Tibet): implications for kinematic change during plateau growth. Tectonics, 35, 1969-1988. https://doi.org/10. 1002/2016TC004229.

Wang, P.-X., Wang, B., Cheng, H., Fasullo, J., Guo, Z. T., Keifer, T., et al. (2017a). The global monsoon across timescales: mechanisms and outstanding issues. Earth-Science Reviews, 174, 84-121.

Wang, W., Zheng, W., Zhang, P., Li, Q., Kirby, E., Yuan, D., et al. (2017b). Expansion of the Tibetan Plateau during the Neogene. Nature Communications, 8, 15887. https://doi.org/10.1038/ ncomms 15887.

Wang, X. X., Deng, L. Z., Zattin, M., Ji, M. X., \& Li, J. J. (2017c). Palaeogene growth of the northeastern Tibetan Plateau: detrital fission track and sedimentary analysis of the Lanzhou basin, NW China. Journal of Asian Earth Sciences, 147, 322-331.

Wang, H., Dutta, S., Kelley, R. S., Rudra, A., Li, S., Zhang, Q. Q., et al. (2018a). Amber fossils reveal the Early Cenozoic dipterocarp rainforest in central Tibet. Palaeoworld, 27, 506-513. https://doi. org/10.1016/j.palwor.2018.09.006.

Wang, Y., Zhang, P., Schoenbohm, L. M., Zheng, W., Zhang, B., Zhang, J., et al. (2018b). Two-phase exhumation along major shear zones in the SE Tibetan Plateau in the Late Cenozoic. Tectonics, 37, 26752694.

Whatley, R., \& Bajpai, S. (2000). Zoogeographical relationships of the Upper Cretaceous nonmarine Ostracoda of India. Current Science, $79,694-696$

White, L., Ahmand, T., Lister, G., Ireland, T., \& Forster, M. (2012). Is the switch from I- to S-type magmatism in the Himalayan Orogen indicative of the collision of India and Eurasia? Australian Journal of Earth Sciences, 59, 321-340.

Winnick, M. J., Chamberlain, C. P., Caves, J. K., \& Welker, J. M. (2014). Quantifying the isotopic "continental effect". Earth and Planetary Science Letters, 406, 123-133.

Wissink, G. K., Hoke, G. D., Garzione, C. N., \& Liu-Zeng, J. (2016) Temporal and spatial patterns of sediment routing across the southeast margin of the Tibetan Plateau: insights from detrital zircon. Tectonics, 35, TC004252. https://doi.org/10.1002/2016TC004252.

Wolfe, J. A. (1979). Temperature parameters of humid to mesic forests of eastern Asia and relation to forests of other regions of the Northern Hemisphere and Australasia. United States Geological Survey Professional Paper, 1106, 1-37.

Wolfe, J. A. (1992). An analysis of present-day terrestrial lapse rates in the western conterminous United States and their significance to paleoaltitudinal estimates. United States Gological Survey Bulletin, 1964, 1-35.

Wolfe, J. A. (1993). A method of obtaining climatic parameters from leaf assemblages: United States Geological Survey Bulletin. United States Geological Survey Bulletin, 2040, 1-73.

Wu, F., Miao, D., Chang, N.-M., Shi, G., \& Wang, N. (2017). Fossil climbing perch and associated plant megafossils indicate a warm and wet central Tibet during the late Oligocene. Scientific Reports, 7, 878-885. https://doi.org/10.1038/s41598-017-00928-9.

Xiong, Z., Ding, L., Wang, X., Spicer, R. A., Farnsworth, A., Wang, X., et al. (2020). The Early Eocene rise of the Gonjo Basin, SE Tibet: from low desert to high forest. Earth and Planetary Science Letters, 543,116312

Xu, R., Tao, J. R., \& Sun, X. J. (1973). On the discovery of a Quercus semicarpifolia bed in Mount Shisha Pangma and its significance in botany and geology. Acta Botanica Sinica, 15, 103-119.

Xu, J. X., Ferguson, D. K., Li, C. S., \& Wang, Y. F. (2008). Late Miocene vegetation and climate of the Lühe region in Yunnan, southwestern China. Review of Palaeobotany and Palynology, 148, 36-59.

Xu, Q., Ding, L., Zhang, L. Y., Cai, F. L., Lai, Q. Z., Yang, D., et al. (2013). Paleogene high elevations in the Qiangtang Terrane, central Tibetan Plateau. Earth and Planetary Science Letters, 362, 31-42.

Xu, Q., Ding, L., Spicer, R. A., Liu, X., Li, S., \& Wang, H. (2018). Stable isotopes reveal southward growth of the Himalayan-Tibetan Plateau since the Paleocene. Gondwana Research, 54, 50-61.

Yan, Y., Carter, A., Huang, C.-Y., Chan, L.-S., Hu, X.-Q., \& Lan, Q. (2012). Constraints on Cenozoic regional drainage evolution of SW China from the provenance of the Jianchuan Basin. Geochemistry, Geophysics, Geosystems, 13, Q03001. https://doi.org/10.1029/ $2011 \mathrm{GC} 003803$.

Yanai, M., \& Wu, G. X. (2006). Effects of the Tibetan Plateau. In B. Wang (Ed.) The Asian Monsoon (pp. 513-549). Berlin: Springer.

Yang, J., Spicer, R. A., Spicer, T. E. V., Arens, N. C., Jacques, F. M. B., $\mathrm{Su}, \mathrm{T}$., et al. (2015). Leaf form-climate relationships on the global stage: an ensemble of characters. Global Ecology and Biogeography, $24,1113-1125$.

Yin, A., \& Harrison, T. M. (2000). Geologic evolution of the HimalayaTibet orogen. Annual Review of Earth and Planetary Sciences, 28 , 211-280.

Zahirovic, S., Müller, R. D., Seton, M., Flament, N., Gurnis, M., \& Whittaker, J. (2012). Insights on the kinematics of the IndiaEurasia collision from global geodynamic models. Geochemistry, Geophysics, Geosystems, 13, Q04W11. https://doi.org/10.1029/ $2011 \mathrm{gc} 003883$.

Zhang, Y. L., Ferguson, D. K., Ablaev, A. G., Wang, Y. F., Li, C. S., \& Xie, L. (2007). Equisetum cf. pratense (Equisetaceae) from the Miocene of Yunnan in southwestern China and its paleoecological implications. International Journal of Plant Sciences, 168(3), 351359. https://doi.org/10.1086/510411. 
Zhang, J. J., Santosh, M., Wang, X. X., Guo, L., Yang, X. Y., \& Zhang, B. (2012a). Tectonics of the northern Himalaya since the India-Asia collision. Gondwana Research, 21(4), 939-960.

Zhang, Q., Willems, H., Ding, L., Gräfe, K.-U., \& Appel, E. (2012b). Initial India-Asia continental collision and foreland basin evolution in the Tethyan Himalaya of Tibet: evidence from stratigraphy and paleontology. Journal of Geology, 120(2), 175-189.

Zhou, Z.-K., Yang, Q.-S., \& Xia, K. (2007). Fossils of Quercus sect. Heterobalanus can help explain the uplift of the Himalayas. China Science Bulletin, 52, 238-247.

Zhu, B., Kidd, W. S. F., Rowley, D. B., Currie, B. S., \& Shafique, N. (2005). Age of initiation of the India-Asia collision in the EastCentral Himalaya. Journal of Geology, 113, 265-285.
Zhu, D.-C., Wang, Q., Cawood, P. A., Zhao, Z.-D., \& Mo, X.-X. (2017). Raising the Gangdese Mountains in southern Tibet. Journal of Geophysical Research - Solid Earth, 122, 214-223. https://doi.org/ 10.1002/2016JB013508.

Zhuang, G., Johnstone, S. A., Hourigan, J. K., Ritts, B. D., Robinson, A., \& Sobel, E. R. (2018). Understanding the geologic evolution of Northern Tibetan Plateau with multiple thermochronometers. Gondwana Research, 58, 195-210. https://doi.org/10.1016/j.gr. 2018.02.014.

Publisher's note Springer Nature remains neutral with regard to jurisdictional claims in published maps and institutional affiliations. 